\title{
Anti-Tumor Efficiency of Perillylalcohol/ $\beta$-Cyclodextrin Inclusion Complexes in a Sarcoma S180-Induced Mice Model
}

\author{
Allan A. Rezende 1,2 ${ }^{1}$, Rafael S. Santos ${ }^{1,2} \mathbb{D}$, Luciana N. Andrade ${ }^{3} \mathbb{D}$, Ricardo G. Amaral $^{3}$, Matheus M. Pereira ${ }^{4} \mathbb{D}$,

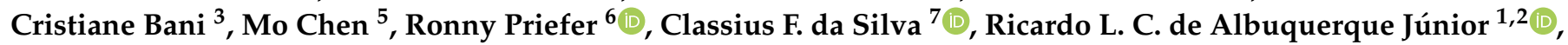 \\ Eliana B. Souto $8,9, * \mathbb{D}$ and Patrícia Severino $1,2,10,11, * \mathbb{D}$
}

check for updates

Citation: Rezende, A.A.; Santos, R.S.; Andrade, L.N.; Amaral, R.G.; Pereira, M.M.; Bani, C.; Chen, M.; Priefer, R.; da Silva, C.F.; de Albuquerque Júnior, R.L.C.; et al. Anti-Tumor Efficiency of Perillylalcohol/ $\beta$-Cyclodextrin Inclusion Complexes in a Sarcoma S180-Induced Mice Model. Pharmaceutics 2021, 13, 245. https:// doi.org/10.3390/pharmaceutics13020245

Academic Editors: Maria Rosaria Lauro and Milos Kojic Received: 15 December 2020

Accepted: 4 February 2021

Published: 10 February 2021

Publisher's Note: MDPI stays neutral with regard to jurisdictional claims in published maps and institutional affiliations.

Copyright: (c) 2021 by the authors. Licensee MDPI, Basel, Switzerland. This article is an open access article distributed under the terms and conditions of the Creative Commons Attribution (CC BY) license (https:// creativecommons.org/licenses/by/ $4.0 /)$.
1 University of Tiradentes (Unit), Postgraduate Program Industrial Biotechnology, and Health and Enviroment Av. Murilo Dantas, 300, 49010-390 Aracaju, Brazil; allan_a.rezende@hotmail.com (A.A.R.); rafa.au@icloud.com (R.S.S.); ricardo.patologia@uol.com.br (R.L.C.d.A.J.)

2 Institute of Technology and Research (ITP), Av. Murilo Dantas, 300, 49010-390 Aracaju, Brazil

3 Department of Physiology, Federal University of Sergipe, São Cristovão, 49100-000 Sergipe, Brazil; luciana.nalone@hotmail.com (L.N.A.); ricardoamaral23@hotmail.com (R.G.A.); crisbani@gmail.com (C.B.)

4 CICECO, Aveiro Institute of Materials, Department of Chemistry, University of Aveiro, 3810-193 Aveiro, Portugal; matheus.pereira@ua.pt

5 Department of Gynecology, Obstetrics \& Gynecology, Obstetrics and Gynecology Hospital of Fudan University, Shanghai 200011, China; chenmo7109@fckyy.org.cn

6 School of Pharmacy, Massachusetts College of Pharmacy and Health Sciences, 179 Longwood Avenue, Boston, MA 02115, USA; ronny.priefer@mcphs.edu

7 Institute of Environmental, Chemical and Pharmaceutical Sciences, Federal University of São Paulo, 09972-270 Diadema, São Paulo, Brazil; classiusferreira@yahoo.com.br

8 Faculty of Pharmacy, University of Coimbra, Pólo das Ciências da Saúde, Azinhaga de Santa Comba, 3000-548 Coimbra, Portugal

9 CEB-Centre of Biological Engineering, University of Minho, Campus de Gualtar, 4710-057 Braga, Portugal

10 Tiradentes Institute, $150 \mathrm{Mt}$ Vernon St, Dorchester, MA 02125, USA

11 Center for Biomedical Engineering, Department of Medicine, Brigham and Women\& Hospital, Harvard Medical School, 65 Landsdowne Street, Cambridge, MA 02139, USA

* Correspondence: ebsouto@ff.uc.pt (E.B.S.); patricia_severino@itp.org.br (P.S.); Tel.: +351-239-488-400 (E.B.S.); +55-79-3218-2190 (P.S.)

Abstract: The low solubility and high volatility of perillyl alcohol (POH) compromise its bioavailability and potential use as chemotherapeutic drug. In this work, we have evaluated the anticancer activity of $\mathrm{POH}$ complexed with $\beta$-cyclodextrin $(\beta-\mathrm{CD})$ using three complexation approaches. Molecular docking suggests the hydrogen-bond between $\mathrm{POH}$ and $\beta$-cyclodextrin in molar proportion was 1:1. Thermal analysis and Fourier-transform infrared spectroscopy (FTIR) confirmed that the $\mathrm{POH}$ was enclosed in the $\beta-\mathrm{CD}$ cavity. Also, there was a significant reduction of particle size thereof, indicating a modification of the $\beta$-cyclodextrin crystals. The complexes were tested against human L929 fibroblasts after $24 \mathrm{~h}$ of incubation showing no signs of cytotoxicity. Concerning the histopathological results, the treatment with $\mathrm{POH} / \beta-\mathrm{CD}$ at a dose of $50 \mathrm{mg} / \mathrm{kg}$ promoted approximately $60 \%$ inhibition of tumor growth in a sarcoma S180-induced mice model and the reduction of nuclear immunoexpression of the Ki67 antigen compared to the control group. Obtained data suggest a significant reduction of cycling cells and tumor proliferation. Our results confirm that complexation of $\mathrm{POH} / \beta-\mathrm{CD}$ not only solves the problem related to the volatility of the monoterpene but also increases its efficiency as an antitumor agent.

Keywords: perillyl alcohol; cyclodextrin; inclusion complex; anti-cancer; sarcoma

\section{Introduction}

Perillyl alcohol $(\mathrm{POH})$ is a monoterpene of essential oils found in large quantities in cherries, lavender, mint, sage, sagebrush, perilla, holy grass (lemongrass), ginger bergamot, ginger leaves, Armenian cumin and seeds of celery. It has been widely used for antineoplastic 
treatment $[1,2]$. The conjugation of $\mathrm{POH}$ with temozolomide was shown to block the induction of the pro-angiogenic process, thus demonstrating to be a potential inhibitor of tumor progression and recurrence in glioma stem cells [3]. In therapy against glioblastoma lineage, the efficacy of $\mathrm{POH}$ administered intranasally has also been described [4,5]. Faria et al. administered $\mathrm{POH}$ by intranasal route in terminally ill patients with glioblastoma and cerebral adenocarcinoma metastasis (stage IV), yielding a 6-month survival rate [6]. In another work, Song et al. described the selectivity of $\mathrm{POH}$ against cancer cell lines with the induction of apoptosis, cytotoxicity and effectiveness in compromising the tumor mitochondrial membrane [7]. These findings make this compound as the most effective of the series against all cell lines [8,9]. $\mathrm{POH}$ is thus recognized as a potent antitumor activity with enormous potential in chemotherapy. However, $\mathrm{POH}$ shows low solubility which compromises its bioavailability, being also associated with a series of gastrointestinal side effects when orally administered.

Cyclodextrins (CDs) have been used to form host-guest inclusion complexes to improve solubility and bioavailability of drugs [10], to which CDs form non-covalent complexes $[11,12]$. In an aqueous solution, the slightly non-polar cavity is occupied by water molecules that are energetically unfavorable. Given the nature of the polar-non-polar interaction, water can be relatively easily replaced by a substrate that is less polar than water. Thus, the driving force for complexation is through the replacement of high-enthalpy water molecules with appropriate substrates [13]. This inclusion does alter drug characteristics significantly by improving bioavailability, solubility, stability and providing controlled release. CDs are widely used as drug carriers in cancer therapy favoring permeation and retention of the drug inside the cell cancer [14]. CDs have been complexed with chemotherapeutic agents against a variety of cancers, for example, bladder [15], colorectal [16], skin [17], lung [18], intestinal [19], colon [20], prostate [21] and liver [22].

There is an increasingly interest in exploring innovative technologies to improve the solubility of drugs $[23,24]$. The use of cyclodextrins as inclusion complexes for such substances is one of the most widely used methods that have been exploited for a range of compounds [25]. Besides, it modifies the drug release profile [26]. In the present work, $\beta$-CD has been selected on the basis of reports successfully describing the synthesis of inclusion complexes [27-29]. Advantages of complexing compounds with $\beta$-CDs are described for non-polar natural products, such as terpenes and essential oils [30]. To our knowledge, our work is the first report describing the complexation of $\mathrm{POH}$ with $\beta-\mathrm{CD}$ and its characterization for potential use as a chemotherapeutic strategy.

The aim of this work has been the synthesis of $\mathrm{POH} / \beta$-cyclodextrin inclusion complexes by different approached, their characterization by Fourier transform infrared (FTIR) and scanning electron microscopy (SEM), molecular docking and thermal analysis to describe the interaction between the drug and the host, as well as their profiling with respect to cell viability in human fibroblast line L929 and anticancer activity in a sarcoma S180 induced mice model.

\section{Materials and Methods}

\subsection{Materials}

Perillyl alcohol (POH) (CAS: 18457-55-1, 98.8\% purity) and $\beta$-cyclodextrin ( $\beta$-CD) (CAS: 7585-39-9, $\geq 97 \%$, molecular weight 1135.01) were purchased from Sigma-Aldrich (St. Louis, MO, USA). All other reagents were also bought from Sigma-Aldrich (St. Louis, MO, USA). The water was supplied by Milli-Q (Millipore, Burlington, MA, USA).

\subsection{Molecular Docking}

Auto-dock vina analyzed molecular interactions between $\beta-\mathrm{CD}$ and $\mathrm{POH}$. The molecular structures created through DS Visualizer to employ molecular coupling. Auto DockTools (ADT, La Jolla, CA, USA) was used to prepare input files by fusing nonpolar hydrogen atoms, adding partial charges and atom types. ADT generated rigid binder root and receiver binder root, defining all possible rotary links as twist-active. The grid at the center 
of mass ( $x, y$ and $z$ axes, respectively) to cover the entire $\beta-C D$ interaction surface was $40 \times 40 \times 40 \AA-10$ different models underwent an assessment to find the binding model with the lowest free energy [31,32].

\subsection{Preparation Perillyl Alcohol/ $\beta-C D$ s Complexes}

The complexation was done by physical mixture, co-evaporation and malaxation using 1:1 molar ratio (POH: $\beta-\mathrm{CD})$, after selection among the tested combinations (1:0.25, $1: 1$ and 1:2) as previously described [33]. The co-evaporation $(\mathrm{CO})$ technique mixed $\beta-C D$ and $\mathrm{POH}$, followed by the progressive addition of distilled water to the formation of a solution and malaxation (MA), consisted of the mixture of $\beta-\mathrm{CD}, \mathrm{POH}$ and $20 \mathrm{~mL}$ of water using magnetic stirring for $36 \mathrm{~h}$. Finally, drying was carried out using a vacuum pump. The physical mixture (PM) was used as control and consisted of lightly homogenized both components with a mortar. All samples were hermetically stored until the characterization [34].

\subsection{Thermal Analysis by DSC and TG/DTG}

Differential scanning calorimetry (DSC) curves (DSC 2010 TA Instruments, New Castle, DE, USA) utilized a temperature range from $25-500{ }^{\circ} \mathrm{C}$, under $\mathrm{N}_{2}$ atmosphere, with a $50 \mathrm{~mL} / \mathrm{min}$ gas flow rate and a $10^{\circ} \mathrm{C} / \mathrm{min}$ heating ratio. The sample holder used was aluminum, containing $2 \mathrm{mg}$ of the sample. Thermogravimetric curves were obtained from Shimadzu TG-60 with temperature ranging from 25 to $900{ }^{\circ} \mathrm{C}$, under nitrogen $\left(\mathrm{N}_{2}\right)$ atmosphere, with a gas flow rate of $50 \mathrm{~mL} / \mathrm{min}$ and a $10^{\circ} \mathrm{C} / \mathrm{min}$ heating ratio. All analyses were performed using a platinum sample holder containing $7 \mathrm{mg}$ of the sample.

\subsection{Fourier-Transform Infrared Spectroscopy (FTIR)}

FTIR spectrum was obtained using Agilent Caryn 630 FTIR (Agilent Technologies, Santa Clara, CA, USA) with attenuated total reflectance device (Miracle ATR, Pike Technologies Spectroscopic Creativity, Madison, WI, USA) using selenium crystal. The spectra were obtained in the $400-4000 \mathrm{~cm}^{-1}$ wavenumber range with resolution $<2 / \mathrm{cm}$ and processed for automatic data acquisition by Agilent Microlab PC software (Agilent Technologies, Santa Clara, CA, USA).

\subsection{Scanning Electron Microscopy (SEM)}

The morphological characteristics of the POH, $\beta-\mathrm{CD}$ and $\mathrm{POH}: \beta-\mathrm{CD}(1: 1)$ produced by CO were analyzed by SEM (Hitachi TM 3000, Tokyo, Japan). The samples were mounted on aluminum stubs, subjected to gold beam metallization and analyzed under an operated $8 \mathrm{Kv}$ voltage acceleration electron microscope [35].

\subsection{Viability Assay}

Viability assay was performed with human fibroblast line L929 based on the ISO 10993-5 [36]. L929 cells (ATCC, LGC Standards S.L.U., Barcelona, Spain) were seeded in 96-well culture plates $\left(2 \times 10^{4}\right.$ cells/well $)$ and cultured in Dulbecco's Modified Eagle's Medium (DMEM) composed of $\mathrm{NaHCO}_{3}(1.2 \mathrm{~g} / \mathrm{L})$, ampicillin $(0.025 \mathrm{~g} / \mathrm{L})$, streptomycin $(0.1 \mathrm{~g} / \mathrm{L})$, supplemented with $10 \%$ fetal bovine serum (SFB). The cells were subjected to different concentrations $(0-150 \mu \mathrm{g} / \mathrm{mL})$ of the samples for $24 \mathrm{~h}$ at $37{ }^{\circ} \mathrm{C}$ and $5 \% \mathrm{CO}_{2}$. Cell viability was assessed using the colorimetric method with Methyl-thiazolyl-tetrazolium (MTT). A solution of $0.025 \mathrm{~g}$ diluted in $50 \mathrm{~mL}$ of PBS was placed in contact with the cells, which were incubated at $37^{\circ} \mathrm{C}$ for $3 \mathrm{~h}$. After removing the MTT, dimethyl sulfoxide (DMSO) was added for $10 \mathrm{~min}$ for the solubilization of the crystals of the tetrazolium salt and soon afterward the optical density (DO) was read in an automated plate reader (ELISA) at a length of $570 \mathrm{~nm}$ wave. The tests were performed in quadruplicate and normalized. 


\subsection{Antitumor Activity}

\subsubsection{Animals}

First, the experimental protocol was submitted and approved by the Animal Care and Use Committee (CEUA) at Tiradentes University under registration number 041217. Twenty Swiss mice (females, weight varying between 25 and $30 \mathrm{~g}$ ) were obtained from the central biotherium of Tiradentes University. The animals were housed and kept under a temperature-controlled room $\left(22-25^{\circ} \mathrm{C}\right)$, with $12: 12 \mathrm{~h}$ light-dark cycle and free access to food and water. Sarcoma 180 (S180) cells were obtained from the Federal University of Sergipe. The donor animal was anesthetized via intraperitoneal and euthanized in a $\mathrm{CO}_{2}$ chamber. A volume of $0.5 \mathrm{~mL}$ of ascitic tumor cells was then aspirated from the animal's abdominal cavity so that viable cells were selected using the trypan blue exclusion method [37]. A cells density of $2 \times 10^{6}$ cells $/ 0.5 \mathrm{~mL} /$ mouse was inoculated into the recipient animals, subcutaneously, in the animal's left axillary region [38,39]. After 24 $\mathrm{h}$ of inoculation, treatments were started to assess the effect of drugs on tumor growth, one application a day for 7 consecutive days. The animals were split in 5 groups $(n=6)$ denominated vehicle (saline $0.9 \%), 5-\mathrm{FU}(25 \mathrm{mg} / \mathrm{kg} /$ day) and $\beta-\mathrm{CD}: \mathrm{POH}(50,100$ and $200 \mathrm{mg} / \mathrm{kg} /$ day). Administration of drugs and saline solution was performed daily by intraperitoneal route. After $24 \mathrm{~h}$ the last day of treatment, the animals were euthanized by induction in a $\mathrm{CO}_{2}$ chamber and the tumors were removed. The specimens were fixed in $10 \%$ formaldehyde for $24 \mathrm{~h}$ and followed a sequence of dehydration steps in increasing concentrations of alcohol, diaphanized in xylol and embedded in paraffin. Subsequently, serial histological sections ( $5 \mu \mathrm{m}$ thick) of each specimen were obtained to perform the histochemical and immunohistochemical techniques. Histopathological analysis of the tumors consisted of each specimen were stained by routine histochemical technique (HE). In these, variables inherent to tumor cells (e.g., cell morphology, degree of cytological atypia and mitotic activity) were analyzed in a descriptive manner and related to tumor/host interaction (e.g., areas of necrosis coagulative, intraparenchymal and peritumoral inflammatory infiltrate and tumor boundaries).

\subsubsection{Proliferative Index in Tumor Cells Using In Situ Immunodetection of Ki67 Antigen}

Histological sections with $3 \mu \mathrm{m}$ thick were mounted on glass slides previously salinized and subjected to immunohistochemistry reaction using the indirect streptavidin-biotin method. The sections were deparaffinized in xylol and washed in decreasing concentrations of ethyl alcohol $(100 \%, 95 \%, 90 \%, 80 \%$ and $70 \%)$. Antigenic recovery was performed by immersing the sections in a citrate solution, heated for $20 \mathrm{~min}$ in a microwave. The marking of the Ki-67 antigen was performed by incubation with the rabbit anti-mouse monoclonal antibody MIB-1 (Dako, Glostrup, Denmark, at 1:50 dilution), for $30 \mathrm{~min}$. The reaction was revealed using diaminobenzidine (DAB, Ventana Medical Systems, Tucson, AZ, USA) and stained against Meyer's Hematoxylin. Both steps were performed at an interval of four min each. The positive control was performed with human tonsil and negative control; the primary antibody was replaced by phosphate-buffered saline in the reaction. The positivity of the immunostaining was evidenced by the visualization of a cellular precipitate in a brownish tone. Thus, cells whose nuclei are immunostained (stained in brown), regardless of the intensity of the staining, were considered positive.

\section{Results and Discussion}

Molecular docking suggests bond simulations between molecules, that is, an efficient link between a macromolecule (receptor) and a small molecule (ligand), in this case between $\beta-\mathrm{CD}$ and $\mathrm{POH}$, respectively, obtained from simulations/homology modeling. Molecule bound profiles have a particular feature of screening virtual libraries of substance-like molecules in order to obtain clues for further drug development. Docking was used to predict the conformation of $\mathrm{POH} / \beta-\mathrm{CD}$ inclusion complex [40] and to estimate bound conformations and binding affinity [41]. 
Figure 1 shows the $\beta-C D$ structure (A and $B$ ) and the inclusion of complex hydrogen bonds $(C$ and $D)$ that occur between $\mathrm{POH}$ and $\beta-\mathrm{CD}$. The best binding position and anchor affinities, interaction molecules, interaction type and geometry distance $(\AA)$ are shown in Table 1. The hydrogen-bonds result from the presence of $\mathrm{OH}$ groups within the $\mathrm{POH}$ structure. This result suggests a stronger bond due to the lower affinity energy [42]. These established hydrogen bonds also suggest that while $\mathrm{CH}_{2}$ and $\mathrm{CH}_{3}$ groups remain exposed, the main $\mathrm{POH}$ molecule is attached to the internal structure of $\beta-\mathrm{CD}$. Molecular docking also allowed us to check the anchoring capacity of different $\mathrm{POH}$ amounts linked to $\beta-\mathrm{CD}$, from which the 1:1 molar ratio was shown to be the most stable structure, thus selected for further studies.

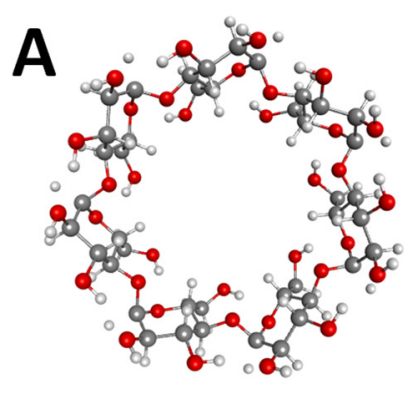

B

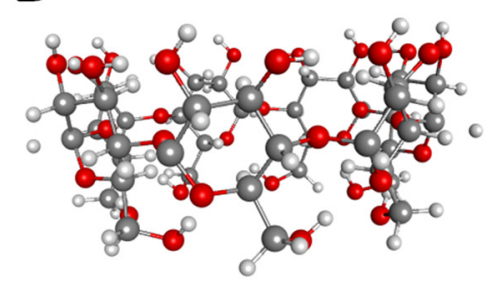

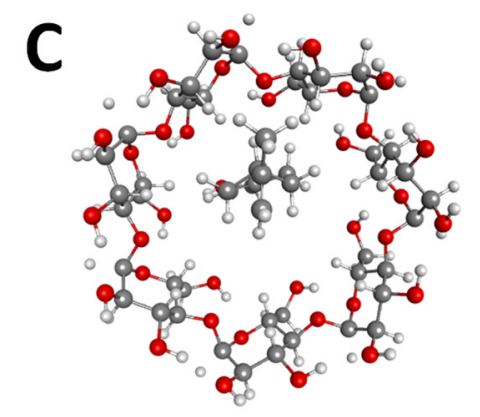

D

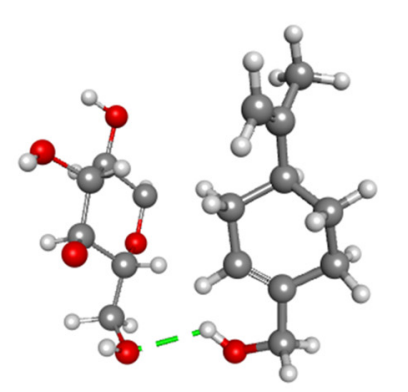

Figure 1. (A) and (B) $\beta-C D$ structure, (C) and (D) molecular docking between $\mathrm{POH}$ and $\beta-\mathrm{CD}$.

Table 1. Molecular docking affinity energy and interaction groups calculated using AutoDock vinna for the $\mathrm{POH} / \beta \mathrm{CD}$ complex.

\begin{tabular}{ccccccc}
\hline Compound & $\begin{array}{c}\text { Affinity } \\
(\mathbf{k c a l} / \mathbf{m o l})\end{array}$ & Interaction & $\begin{array}{c}\text { Interaction } \\
\text { Type }\end{array}$ & From & To & Distance (A) \\
\hline Perillyl Alcohol & -4.0 & $\mathrm{O}$ & Hydrogen Bond & $\begin{array}{c}\text { Perillyl Alcohol } \\
(\mathrm{OH} \text { in C10) }\end{array}$ & $\beta \mathrm{CD}(\mathrm{OH}$ in C6) & 2.23 \\
\hline
\end{tabular}

$\mathrm{POH}, \beta-\mathrm{CD}$ and the complexes obtained upon physical mixture (PM), malaxation (MA) and co-evaporation (CO) were subjected to the analysis by DSC and TG/DTG. Figure S1 (Supplementary material) shows the DSC curve of $\beta$-CD depicting two endothermic peaks; the first recorded between 37.44 and $108.35^{\circ} \mathrm{C}(-427.66 \mathrm{~J} / \mathrm{g})$ and the second between 300.45 and $346.99^{\circ} \mathrm{C}(-578.10 \mathrm{~J} / \mathrm{g})$, attributed to water evaporation and decomposition, respectively. $\mathrm{POH}$ displayed a broad endothermic peak between 26.02 and $94.42{ }^{\circ} \mathrm{C}$ $(-257.22 \mathrm{~J} / \mathrm{g})$, corresponding to its volatilization.

The DSC curves of the raw materials ( $\mathrm{POH}$ and $\beta-\mathrm{CD}$ ) compared to those obtained by the analyses of the complexes (CO, PM and $\mathrm{MA}$ ) confirm that the best interaction between the $\mathrm{POH}$ and $\beta-\mathrm{CD}$ was obtained with $\mathrm{CO}$ methodology; the $\mathrm{POH}$ reduction of the melting endotherm $\left(73.14\right.$ to $\left.127.40^{\circ} \mathrm{C},-29.41 \mathrm{~J} / \mathrm{g}\right)$ was more significant compared to other methodologies (PM and MA). PM and MA show two endothermic peaks similar to the raw material's profile, indicating the presence of the free form of $\beta$-cyclodextrin. The $\mathrm{CO}(\mathrm{POH}: \beta-\mathrm{CD}, 1: 1)$ thermogram suggests that this method offers a more efficient 
complexation, attributed to the incorporation of $\mathrm{POH}$ in the internal cavity of $\beta-\mathrm{CD}$. The melting event of $\mathrm{POH}$ shows a reduction in its peak. Additionally, during complexation, the water molecules present in the $\beta-C D$ are removed and replaced by the guest molecule, thus favoring the formation of the complex and changing the thermoanalytical curve of the systems. Compared to CO, MA and PM approaches showed a smaller reduction in the melting peaks.

The formation of the POH/ $\beta-\mathrm{CD}$ inclusion complex was also studied by TG/DTG. Figure S2 (Supplementary material) shows the TG curves of $\mathrm{POH}$ and $\beta-\mathrm{CD}$ raw materials and the complexes obtained by $\mathrm{CO}, \mathrm{PM}$ and MA. From the depicted data, the POH suffers decomposition and volatilizes before $100{ }^{\circ} \mathrm{C}$ is reached. $\beta$-CD shows a thermoanalytical profile, which can be split into four parts. The first depression involves water loss $(12.97 \%)$. Between 100 and $250{ }^{\circ} \mathrm{C}$, the TG curve is flat and a low mass loss is detected $(0.32 \%)$ and the thermal decomposition (around 89.70\%) occurs between 250 to $500{ }^{\circ} \mathrm{C}$ (confirmed by DTG). Then continuous carbonization occurs in a wide temperature range that is, from $500{ }^{\circ} \mathrm{C}$ to about $700{ }^{\circ} \mathrm{C}(\Delta m=4.97 \%)$. A similar result has been described by Menezes et al. [43]. A similar profile was observed for the PM, which shows the overlap of individual components indicating low interaction (and therefore low degree of interaction) between $\mathrm{POH}$ and $\beta-\mathrm{CD}$. In the TG analyses of complexes, the first mass loss event can be attributed to the water evaporation. A reduction of the intensity of this step can be seen in the DTG curve of the inclusion complex obtained by $\mathrm{CO}$; this indicates the higher probability of replacing water molecules in the $\beta-C D$ cavity with the monoterpene. According to Mura et al. [44], this can be explained by favoring hydrophobic interactions between $\mathrm{POH}$ and the nonpolar cavity of the $\beta-C D$ resulting in a lower energy state, which favors the formation of the new structure. Then, a second, more pronounced mass loss event was seen, which corresponds to the degradation of $\beta-C D$. The data obtained by TG are in agreement with those recorded by DSC (Figure S1, Supplementary material).

FTIR is useful to monitor the formation of an inclusion complex in the sample [45]. Figure 2 displays the FTIR spectra of POH, $\beta-\mathrm{CD}$ and complexes obtained by PM, MA and $\mathrm{CO}$. $\mathrm{POH}$ exhibited typical $\mathrm{OH}$ (free) axial deformations bands, characteristic of the hydroxyl group at $3596.8 \mathrm{~cm}^{-1}$, alkene $\mathrm{CH}$ at $3009.8 \mathrm{~cm}^{-1}$ and $\mathrm{C}=\mathrm{C}$ at $1667.9 \mathrm{~cm}^{-1}$. Additionally, the bands observed in the $1500-1300 \mathrm{~cm}^{-1}$ region correspond to the $C-C$ stretch absorption bands of the ring. The absorption bands $\beta-C D$ shown between 3718 $3072 \mathrm{~cm}^{-1}$ are reference $\mathrm{OH}$ group vibration and a strong band is seen from $3000 \mathrm{~cm}^{-1}$ to $3300 \mathrm{~cm}^{-1}$, resulting from the $\mathrm{OH}$ group stretching, which suggests water loss and subsequent hydrogen bond breakage and $\mathrm{POH}$ inclusion. Similar findings were reported by Trindade et al. [21], who also verified cyclic structure $\mathrm{C}-\mathrm{H}$ at $2800 \mathrm{~cm}^{-1}, \mathrm{C}-\mathrm{O}$ stretch bands at $900 \mathrm{~cm}^{-1}$ and $C=C$ at $1604 \mathrm{~cm}^{-1}$ and $1375 \mathrm{~cm}^{-1}$. PM spectra showed an overlap of the individual $\mathrm{POH}$ and $\beta-\mathrm{CD}$ bands, suggesting a weak interaction between $\mathrm{POH}$ and $\beta-C D$. Analyzing inclusion complexes spectra from MA and $\mathrm{CO}$ samples, there is an $\mathrm{O}-\mathrm{H}$ axial deformation characterized by a narrow absorption band around $3500-3000 \mathrm{~cm}^{-1}$. Changes in intensity at this broad peak was associated with inclusion complex formation towards lower wavenumbers and decrease in intensity and broadening, upon complexation [46]. Also, a significant reduction in the $\mathrm{POH}$ characteristic absorption bands occurs probably due to a vibration restriction following the complexation process. The inclusion complex showed small differences in comparison to that of PM and the raw materials, indicating the presence of a weakly bound, as a hydrogen bond [47].

Figure 3 shows the SEM of the $\beta-C D$ and the $\beta-C D: P O H ~(1: 1)$ produced by CO methodology at $500 \times$ magnification. Pure $\beta-C D$ appears as crystalline particles of different sizes without a defined shape. The inclusion complex showed a significant reduction of particles, resulting in compact and homogeneous agglomerates which indicate a modification of the crystal and the powder. When the $\mathrm{POH}$ is complexed in the $\beta-\mathrm{CD}$ cavity, the crystallinity of the complex resulted in a more amorphous character. SEM results show the homogenous $\beta-\mathrm{CD}$ crystal after the POH inclusion. Similar results were also obtained with other monoterpenes, as $\alpha$-terpineol [35], carvacrol [48] and citronellal [49]. 


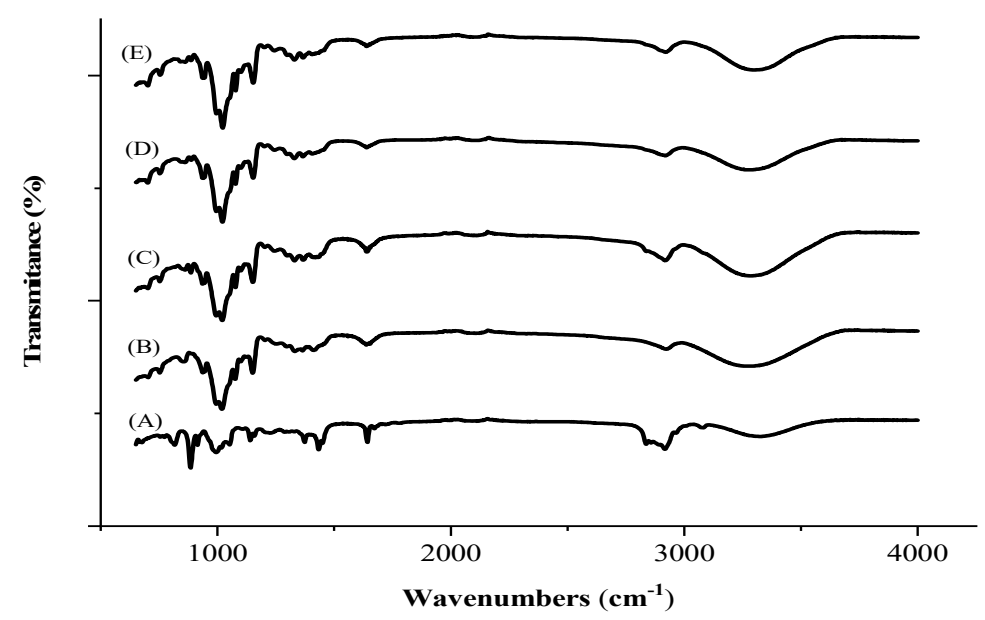

Figure 2. Fourier transform spectrophotometry (A) Perillyl alcohol, (B) $\beta$-cyclodextrin, (C) Coevaporation, (D) Malaxation and (E) Physical mixture.

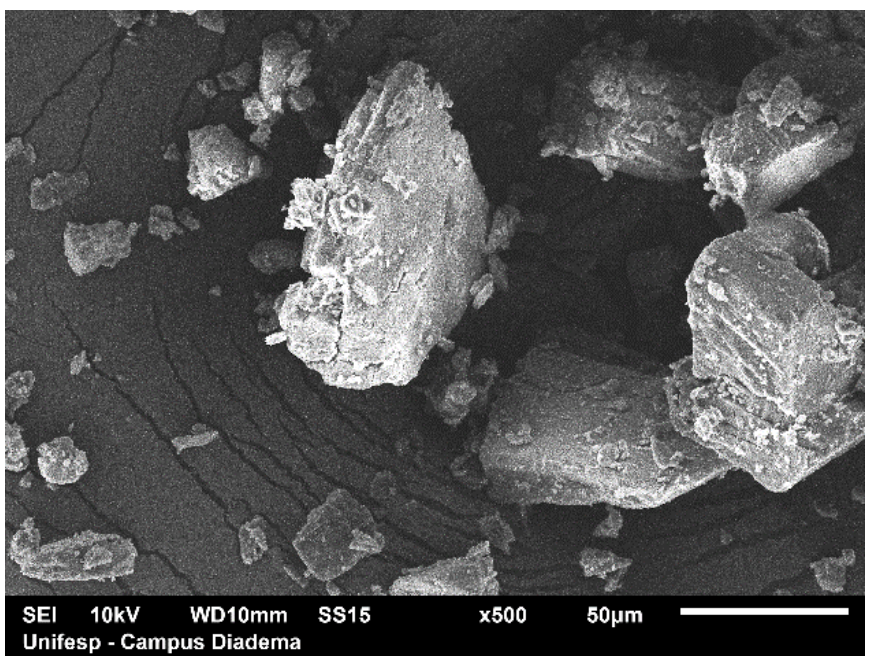

(A)

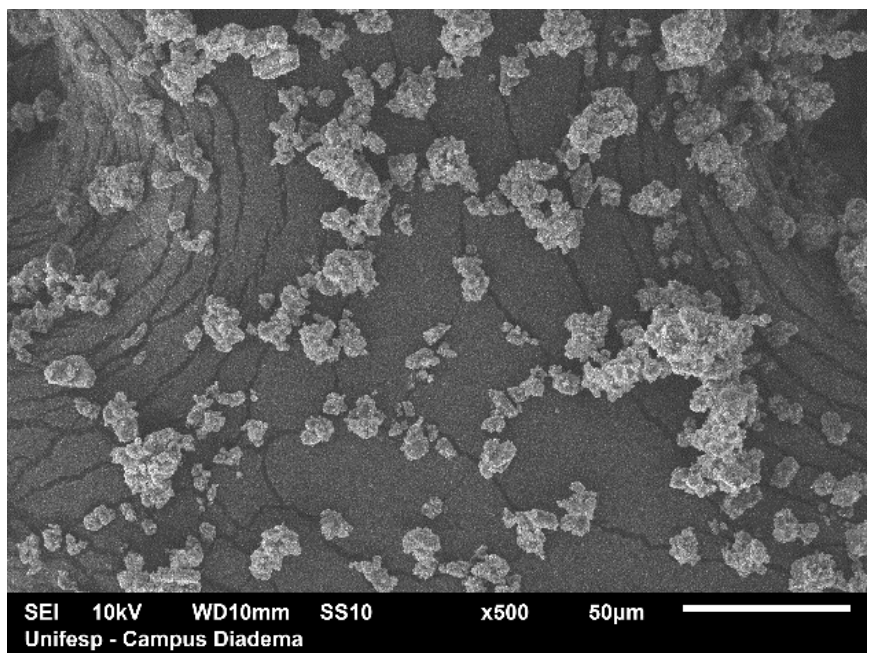

(B)

Figure 3. Scanning electron microscopy (SEM) images of (A) $\beta$-cyclodextrin ( $\beta$-CD), (B) Co-evaporation.

The results obtained in the present work indicate that for $\mathrm{POH}$ and for the inclusion complexes containing or not the monoterpene, resulted in $100 \%$ viability of human L929 fibroblasts after $24 \mathrm{~h}$ of incubation (Figure 4). These data suggest that both the isolated compound and the complex form are non-toxic to non-malignant cells, further demanding its evaluation in in vivo models.

Antitumor therapy encounters serious adverse effects due to the nonspecific action of antineoplastic drugs, which can trigger damage both in tumor cells and in healthy cells, compromising the homeostasis of healthy tissues [50]. Antineoplastic drugs induce a variety of metabolic damages to the patient, such as gastrointestinal disorders, nausea and immunosuppression, rashes, arthralgia, adynamia, neuro and nephrotoxicity, among countless others, in addition to the development of clinical resistance [51]. Thus, the search for more selective, effective and/or less aggressive drugs to reduce these side effects is essential for a successful antineoplastic therapy. An increasingly growing interest in the search for products for anticancer therapy has been seen to promote the elimination or inhibition of tumor growth [52]. The potential antineoplastic activity of the complex has been evaluated in a sarcoma 180 (S180) bearing mice. This model has the advantage of being easily handled for the implantation protocol, tumor growth up to $90 \%$ to $100 \%$ and rapid tumor evolution, which reduces the experimentation time [39]. 


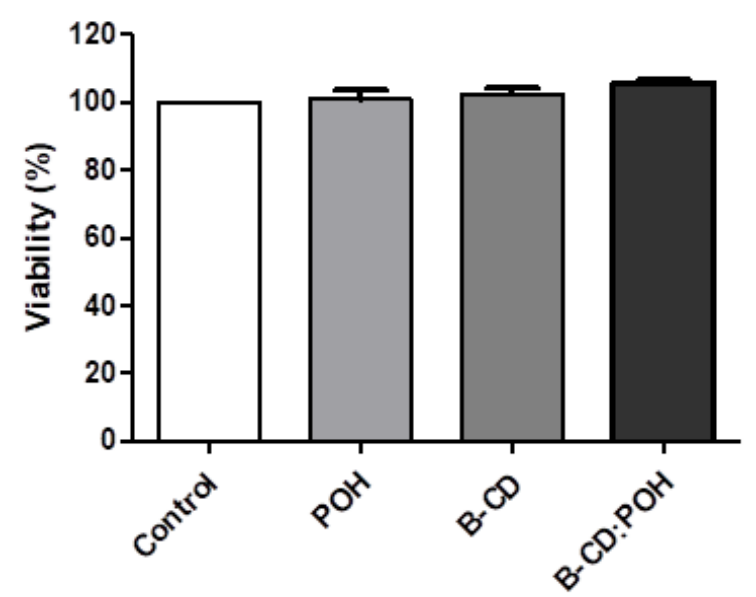

Figure 4. Effect of perillyl alcohol (POH), $\beta$-cyclodextrin and $\beta$-CD: $\mathrm{POH}(1: 1)$ on the viability of human L929 fibroblasts determined by the MTT assay after $24 \mathrm{~h}$ of incubation. The negative control (C) was treated with the vehicle used to dissolve the drug (DMSO 5\%). The data correspond to the mean \pm S.E.M. of four independent experiments.

The histological analysis of tumors observed in the vehicle group were characterized by the formation of sheets and solid blocks of neoplastic cells, which deeply infiltrated the dermo-hypodermic tissue. In the dermal portion of the tumor, a discontinuous pseudocapsule was formed by loose fibrous connective tissue, with inflammatory reaction and moderate-intensity interstitial edema and infiltrated by neoplastic cells. The tumors exhibited extensive areas of intraparenchymal coagulative necrosis, forming large masses of irregularly shaped borders, which, in general, occupied more than $50 \%$ of the tumor area. Individually, parenchymal cells showed strong atypia, expressed by nuclear hyperchromatism and cellular pleomorphism, while unusual giant tumor cells were relatively frequent findings (Figure 5a). Also, mitotic activity was abundant, with the presence of typical and atypical mitosis figures. The infiltration of deep muscle planes is also quite evident; often, the tumor cells exhibited strong dissociation and were arranged in thin strands like the "Indian row". Areas of perineural and lymphovascular invasion (formation of neoplastic cell emboli) were eventually observed in only two cases (Figure 5b). The massive infiltration of the hypodermic adipose panicle by neoplastic cells was also shown to be a frequent morphological finding. It was possible to evidence areas of neoformation of irregular capillary vessels, many of them hyperemic, both on the periphery of the tumor and inside the solid sheets of neoplastic cells. The inflammatory infiltrates present, albeit in mild to moderate intensity, were composed of lymphocytes and histiocytes, usually concentrated on the tumor margins and polymorphonuclear neutrophils, the latter particularly evident in the perinecrotic areas (Figure $5 c$ ).

5-FU group formed solid blocks of neoplastic cells exhibiting moderate atypia, still showing a balance between the number of cells with dense nuclear chromatin (hyperchromatic) and those with finely dispersed chromatin and sometimes with one to two prominent nucleoli. Tumor cells insinuated themselves in the connective tissue and invaded the skeletal striated musculature, sometimes severely dissociating the muscle bundles and adipose panicle and, at other times, separating them into compact and relatively well-preserved blocks or lobes, which denoted less invasive capacity/infiltration of tumor parenchymal cells. The areas of coagulative necrosis were less evident and are presented in the form of thin depicting a pseudolobular architectural aspect. There was also the presence of a peripheral fibrous pseudocapsule, well-marked but thin and discontinuous (Figure 6a). The mitotic activity proved to be infrequent and composed of a typical structure. Areas of intense intratumoral inflammatory infiltrate, rich in lymphocytes, macrophages and neutrophils were also evident. Moreover, the inflammatory infiltrate was also intense in the marginal tumor areas, especially in the pseudocapsule (peripheral fibrous connective tissue, particularly visible in the superficial portion of the tumors) (Figure 6b). 

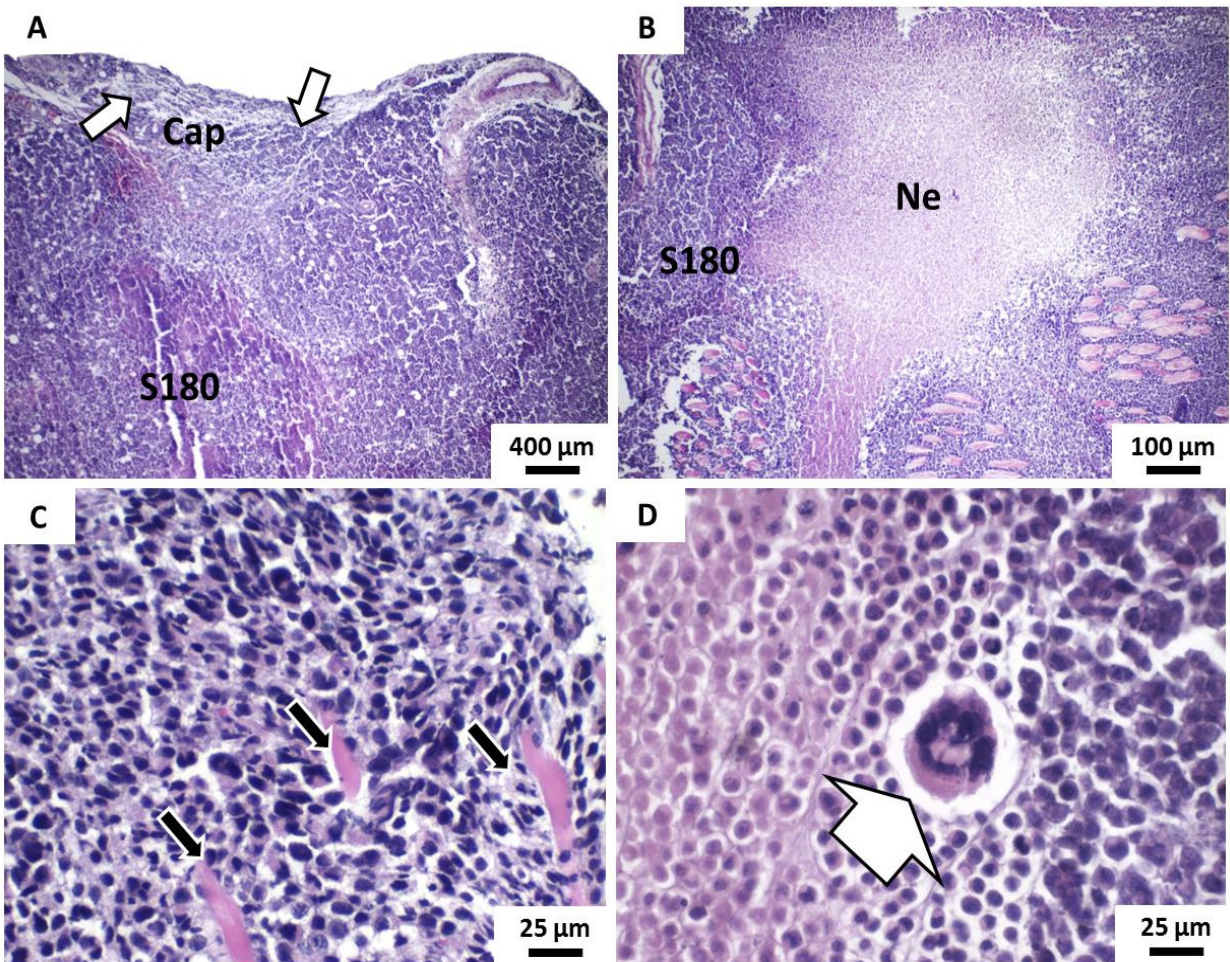

(a)
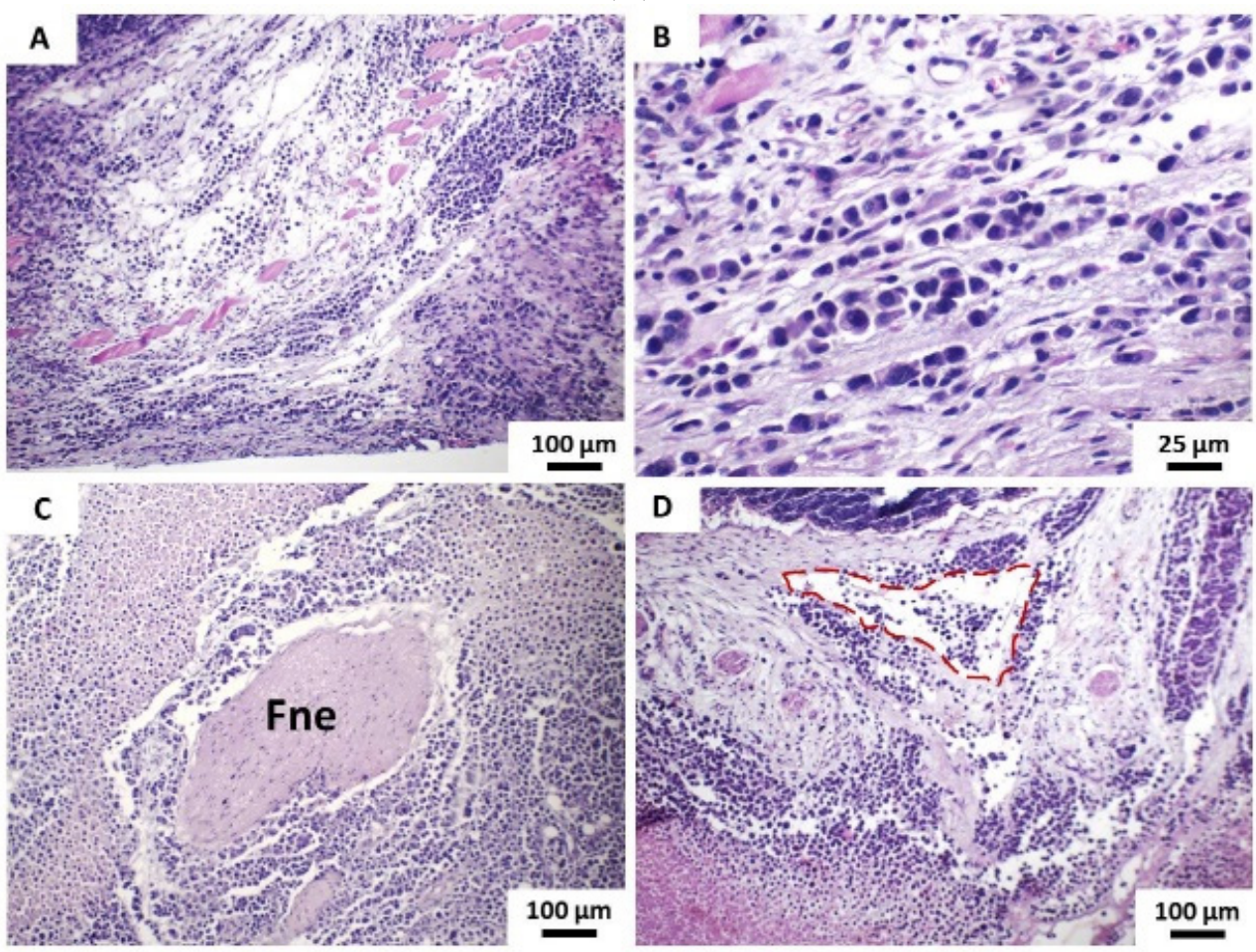

(b)

Figure 5. Cont. 

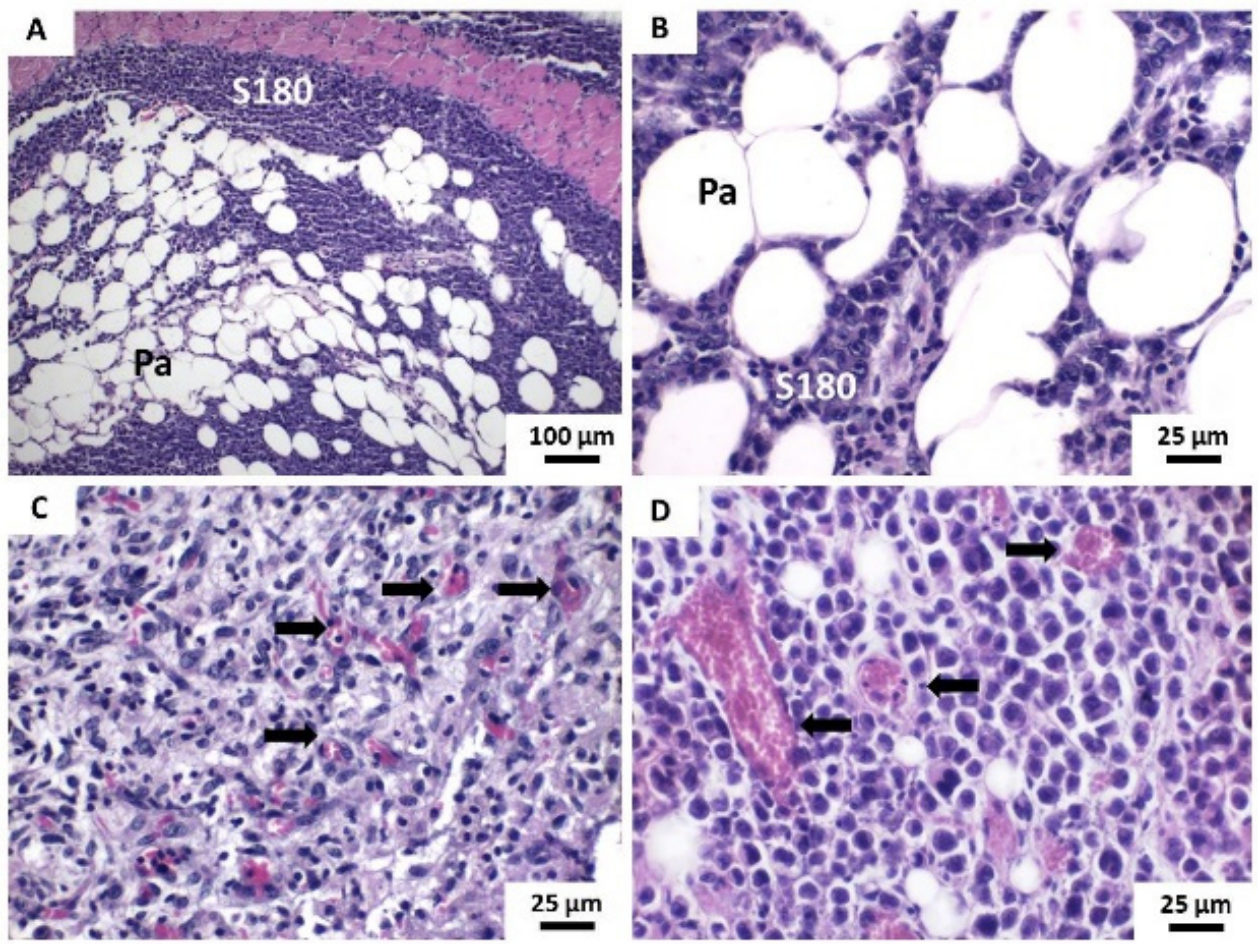

(c)

Figure 5. (a) Photomicrographs of histochemical technique (HE)-stained histological sections show the main histopathological features of tumors developed in the Vehicle group from the implantation of S100 cells. (A) The dermal superficial margin of the tumor shows discontinuous pseudocapsule (Cap) showing evident neoplastic infiltration (white arrows) $(40 \times)$ and (B) extensive areas of coagulative necrosis $(\mathrm{Ne})$ within the neoplastic cell blocks $(40 \times)$. (C) Detail of tumor cells exhibit intense atypia and promote dissociation and destruction of striated skeletal muscle fibers (black arrows) $(400 \times)$ and (D) Bizarre giant tumor cell $(400 \times)$; (b) (A) Neoplastic cells promote infiltration and massive destruction of striated skeletal muscle fiber bundles $(100 \times)$, (B) Strongly dissociated tumor cells arranged in "Indian row" cords $(400 \times)$. (C) Neoplastic cells promote perineural invasion of peripheral nerve fibers (Fne) $(100 \times)$. (D) Neoplastic cells observed inside the lymphatic vessel form a tumoral embolus (red outline) $(100 \times)$ and (c) (A) and (B) Neoplastic cells (S180) promote massive infiltration of the hypodermic adipose panicle $(\mathrm{Pa})(100 \times$ and $400 \times$, respectively). (C) Intense capillary vascular neoformation (black arrows) on the periphery of the tumor and (D) in intraparenchymal areas $(400 \times)$.

$\mathrm{POH} / \beta-\mathrm{CD} 50 \mathrm{mg} / \mathrm{Kg}$ group presented histological characteristics similar to those evidenced in the 5-FU group, expressed by an architectural arrangement of tumor cells also in irregular pseudolobules, now separated by edematous fibrous connective tissue and rich in inflammatory cells, sometimes separated by necrotic trabeculae tissue. It was observed that the proportion of areas of coagulative necrosis shown in this group was higher than in the 5-FU group (Figure 7a). The invasion pattern of striated skeletal muscle tissue and subcutaneous adipose panicle by tumor cells was also similar to the 5-FU group, with tissue dissociation in dense and compact blocks of muscle fibers and fat cells. Mitotic activity was still marked but seldom atypical mitosis (Figure 7b). 

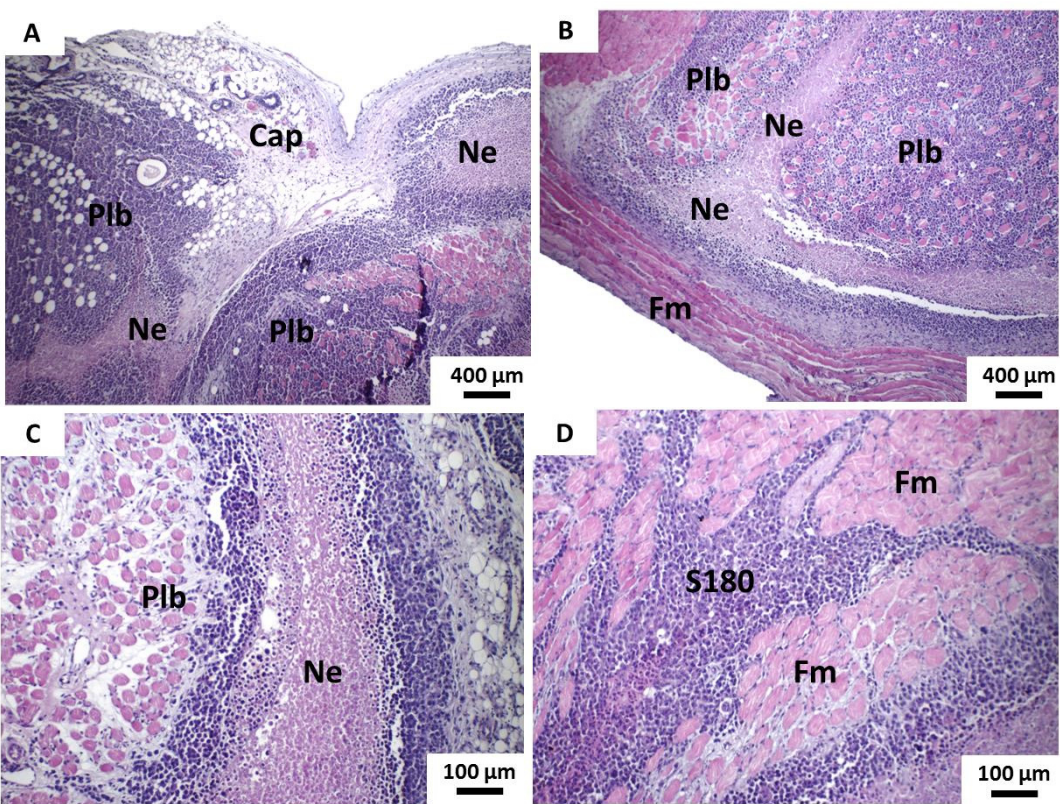

(a)

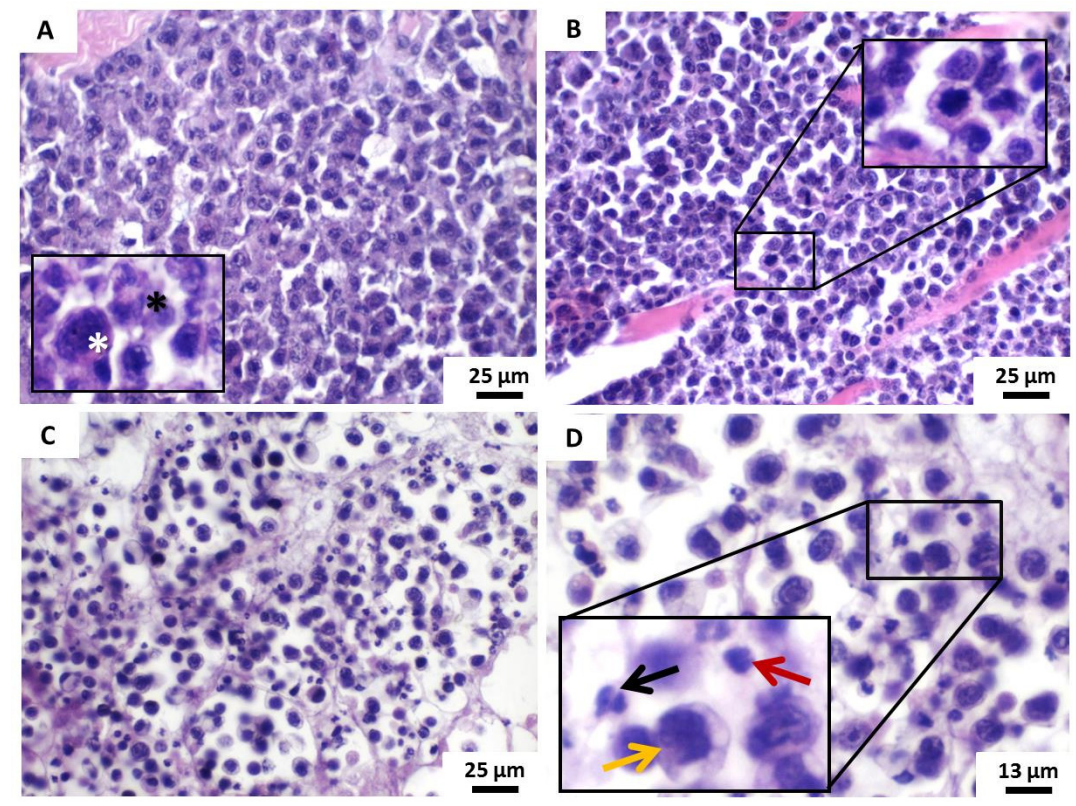

(b)

Figure 6. Photomicrographs of histological sections stained in HE show the main histopathological features of tumors developed in the 5-FU group from the implantation of S180 cells. (a) (A) The superficial area shows pseudocapsule and blocks of tumor cells separated by necrotic tissue trabecular, giving a pseudolobular aspect $(40 \times)$. (B) Deep portion facing the hypodermis shows, in a similar way, the necrotic trabecular that separate blocks of tumor cells into pseudolobules; note the marked delimitation of the tumor by striated skeletal muscle fibers $(40 \times)$. (C) Detail of the narrow bands of necrotic tissue (trabic) separating the pseudolobules $(100 \times)$. (D) The central portion of the tumor shows tumor cells that invade bundles of muscle fibers, separating them into relatively well-preserved blocks $(100 \times)$. Caption: Cap—superficial pseudocapsule; Coagulative necrosis; Plb—pseudolobules; Fm-skeletal striated muscle fibers; S180-viable sarcoma 180 tumor cells and (b) (A) Tumor cells showing mild to moderate atypia, with cells sometimes showing nuclei of chromatin, sometimes dense (white asterisk), sometimes dispersed (black asterisk) $(400 \times$, detail in $800 \times)$. (B) Figure of typical mitosis in prophase $(400 \times$, detail in $800 \times)$. (C,D) Intense inflammatory infiltrate and interstitial edema in the middle of the tumor parenchyma $(400 \times$ and $800 \times$, respectively; details in $1500 \times)$. Legend: Yellow arrow—Tumor cell; Black arrow—neutrophil polymorphonuclear; Red arrow-lymphocyte. 

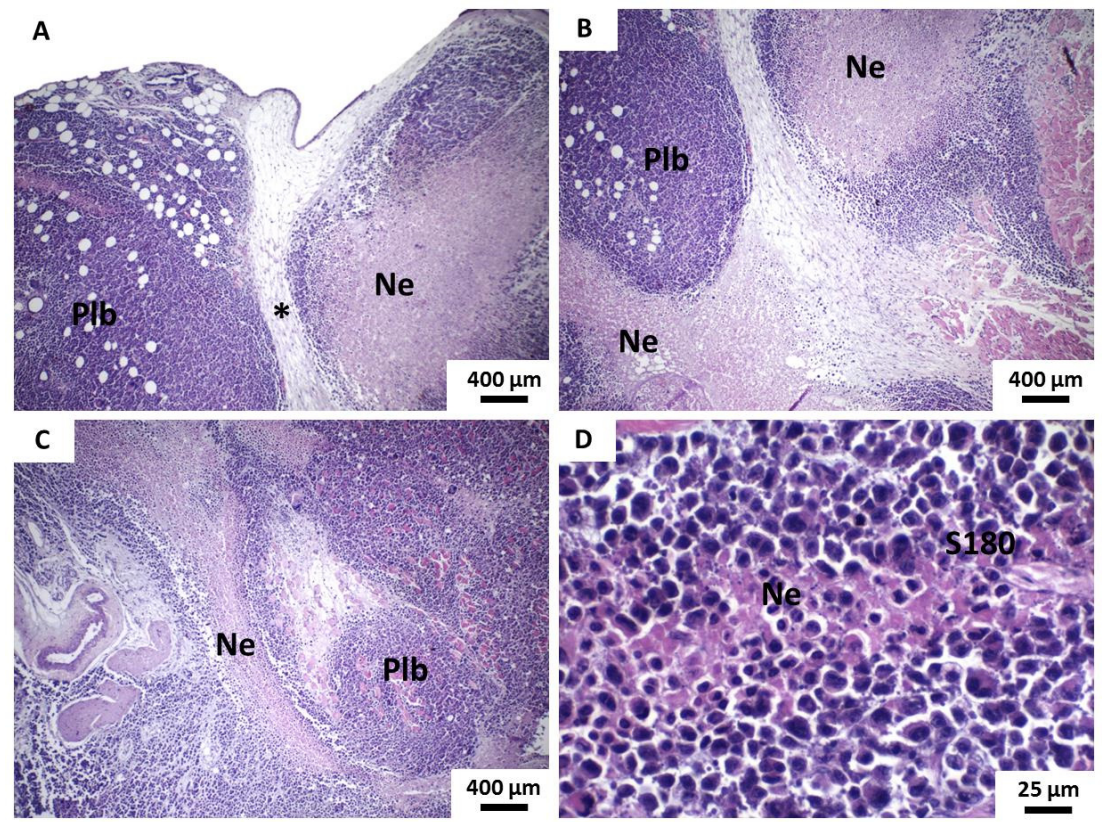

(a)
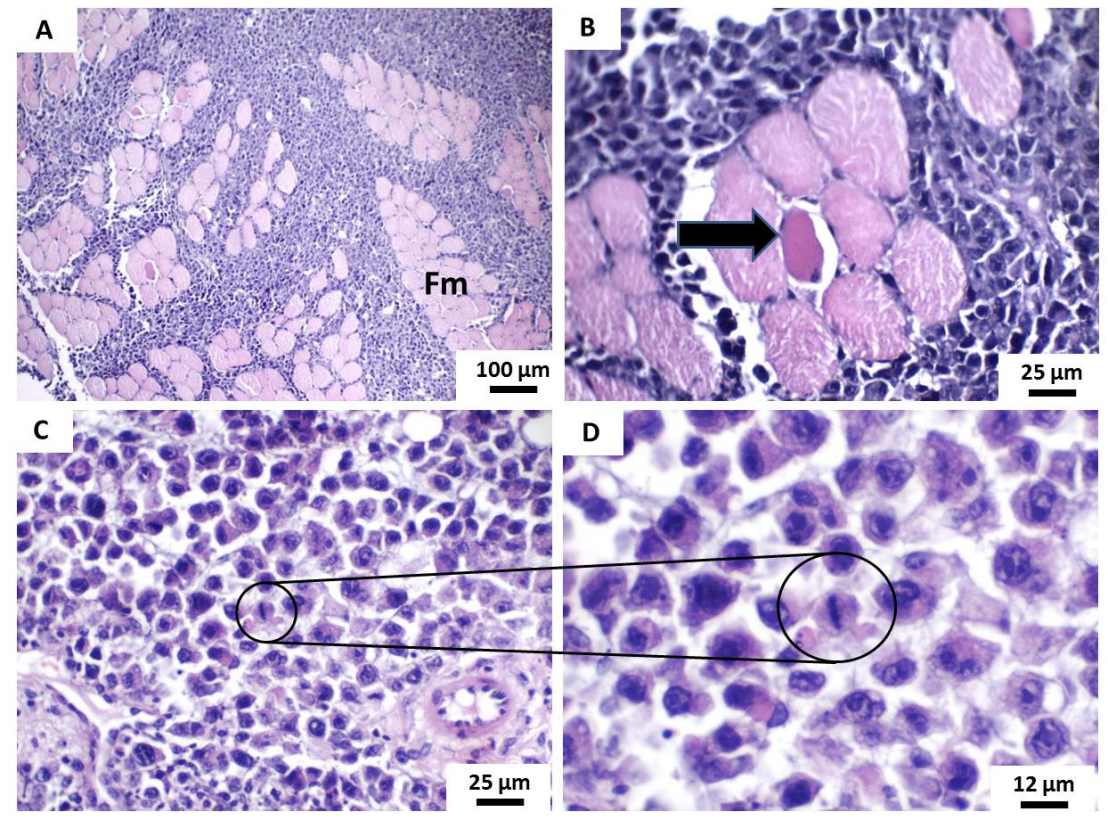

(b)

Figure 7. Photomicrographs of histological sections stained in HE show the main histopathological features of tumors developed in the $\beta-\mathrm{CD}: \mathrm{POH} 50 \mathrm{mg} / \mathrm{Kg}$ group from the implantation of $\mathrm{S} 180$ cells. (a) (A-C) Tumor cells organized in a pseudolobular pattern (sometimes septated by fibrous connective tissue and sometimes by irregular bands of necrotic tissue) $(40 \times)$. (D) Small necrotic tissue trabic amid tumor sheet cells $(400 \times)$. Caption: Coagulative necrosis; Plb-pseudolobules; S180-viable sarcoma 180 tumor cells and (b)(A) Tumor cells infiltrate and dissociate solid blocks of muscle fibers $(\mathrm{Fm})(100 \times)$. (B) Apoptosis of muscle cell (black arrow) in response to tumor infiltration $(400 \times) .(C)$ Atypical tumor cells showing low cohesivity and mitotic activity $(400 \times)$. (D) Detail mitotic figure of tumor cell in metaphasis $(800 \times)$.

$\mathrm{POH} / \beta-\mathrm{CD} 100$ and $200 \mathrm{mg} / \mathrm{Kg}$ groups presented similar histological characteristics, characterized by more dense neoplastic proliferation, without lobulation or apparent pseudolobulation, with areas of extensive necrosis both within the tumor mass and in the marginal areas. The inflammatory reaction was limited to tumor margins and perinecrotic 
areas. The tumoral boundaries were shown to be irregular and strong dissociation and destruction of striated skeletal muscle fibers were observed. Besides, mitotic activity was expressive but with rare atypical (Figure 8). The degree of cytological atypia proved to be highly variable between the various tumors, sometimes milder and sometimes more intense; however, giant cells were rarely seen while morphological signs of the perineural or vascular invasion were not observed.

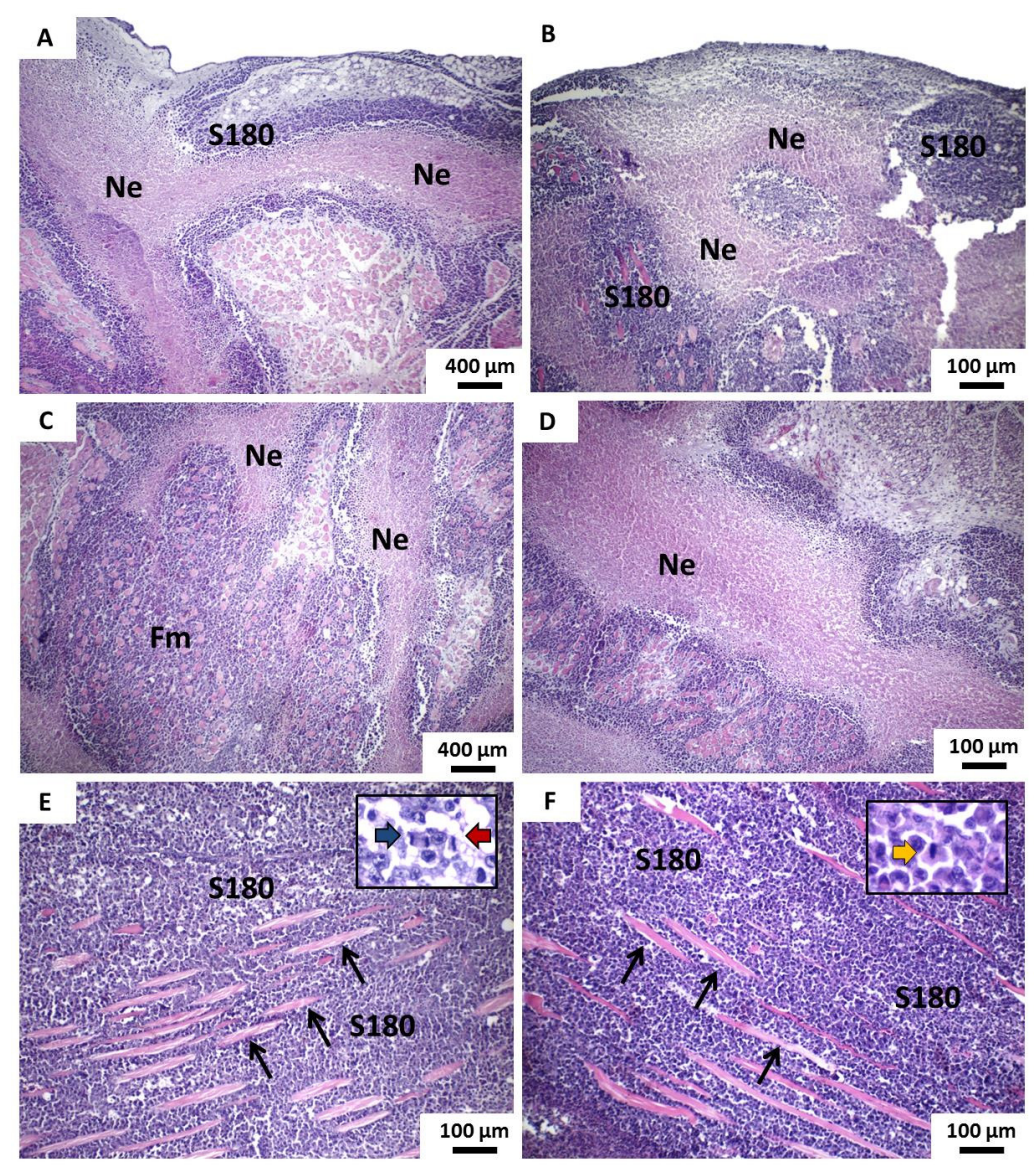

Figure 8. Photomicrographs of HE stained histological sections show the main histopathological features of tumors developed in groups $\beta-\mathrm{CD}: \mathrm{POH}(100$ and $200 \mathrm{mg} / \mathrm{Kg})$ from the implantation of S180 cells. (A,B) Irregular tumor boundaries and areas of peripheral coagulative necrosis and (C,D), as well as extensive blocks of necrosis in the most central areas of the tumor masses observed in groups $\beta$-CD:POH $100 \mathrm{mg} / \mathrm{Kg}$ and $200 \mathrm{mg} / \mathrm{Kg}$, respectively $(100 \times)$. (E) Intense dissociation of muscle fibers by tumor cells in both groups $\beta-\mathrm{CD}: \mathrm{POH} 100 \mathrm{mg} / \mathrm{Kg}$ and $(\mathrm{F}) \beta-\mathrm{CD}: \mathrm{POH} 200 \mathrm{mg} / \mathrm{Kg}(100 \times)$. In the details, there are figures of mitosis in different phases of the cell cycle $(400 \times)$. Legend: S180 — Viable tumor cells of sarcoma 180; Coagulative necrosis; Thin black arrows—striated skeletal muscle fibers; Blue arrow-anaphase mitosis; Red arrow-metaphase mitosis; Orange arrow—prophase mitosis.

Concerning the histopathological results, the treatment with $\mathrm{POH} / \beta-\mathrm{CD}$ at a dose of $50 \mathrm{mg} / \mathrm{kg}$ promoted approximately $60 \%$ inhibition of tumor growth in mice. The mechanisms of action that determine this biological activity are not yet fully elucidated but there are indications, in the literature, of direct and indirect action by the $\mathrm{POH}$ on malignant neoplasms. It has been shown that $\mathrm{POH}$ promotes inhibition of the Ras signaling pathway and, consequently, cell proliferation and apoptosis induction in the phase of promoting dermal carcinogenesis [53]. On the other hand, it has recently been reported that $\mathrm{POH}$ can block the transition of the phenotype of undifferentiated mesenchymal cells into endothelial cells (mesenchymal-endothelial transition or TMEnd) derived from human multiform glioblastomas [3]. The authors believe that, as EndTM is essential for the development of tumor angiogenesis phenomena, supporting neoplastic nutrition, this 
inhibitory effect could, indirectly, inhibit tumor progression and recurrence. However, further studies are needed to prove.

It should also be noted that the intensity of tumor inhibition of the $\mathrm{POH} / \beta-\mathrm{CD}$ (50 mg/kg) was similar to that described by Andrade et al. [37], using free $\mathrm{POH}$ in a dose 4 times greater $(200 \mathrm{mg} / \mathrm{kg})$. These data suggest that the technological strategy of complexing this monoterpene into $\beta$-cyclodextrin inclusion complexes $(\mathrm{POH} / \beta-\mathrm{CD})$ not only solves the problems related to the volatility of the compound but also increases its efficiency as an antitumor agent, as it allows obtaining similar results at much lower doses. This increase in the pharmacological activity of bioactive compounds after inclusion into cyclodextrin complexes is well defined in the literature [30] and supports the results obtained in our study.

Besides, the groups treated with $5-\mathrm{FU}$ and $\mathrm{POH} / \beta-\mathrm{CD}(50 \mathrm{mg} / \mathrm{kg})$ presented distinct morphological characteristics compared to others. The lower degree of tumor necrosis, less mitotic activity and better definition of tumor borders, sometimes showing areas of peritumoral fibrosis. The mitotic index provides evidence about tumor proliferative activity; the formation of areas of necrosis is often associated with cell proliferation so intense and rapid that neovascularization does not occur with the speed necessary to provide nutrition to tumor cells and, thus, suggesting high proliferative activity; lymphocytic peritumoral fibrosis provide evidence about the interaction between tumor and host tissues [54]. Thus, it is possible to speculate that such findings, almost not observed in the other groups, could be related to a less aggressive biological behavior of tumors treated with 5-FU and $\mathrm{POH} / \beta-\mathrm{CD}(50 \mathrm{mg} / \mathrm{kg})$.

Tumor proliferation was analyzed using in situ immunostaining of the Ki67 antigen. This protein is expressed in the cell nucleus in all phases of the cell cycle (G1, S, G2 and M), is widely used as an indicator of cell proliferation and even tumor prognosis $[55,56]$. In this sense, tumors with high proliferative indices (strongly positive for the Ki67 antigen) would show more aggressive biological behavior, the opposite being true for those with lower proliferative indices (showing weak positivity for Ki67).

Immunostaining for Ki67 antigen was observed in all analyzed samples but the immunostained cells varied significantly between specimens. Although immunohistochemical positivity has been evidenced mainly in the cell nucleus, in many cases the cytoplasmic/membranous expression of this antigen has also been identified in tumor cells. However, only nuclear immunostaining was considered for quantitative analysis of the proliferative tumor index. The distinct morphological characteristics suggest a less aggressive tumor behavior in the groups treated with 5-FU and $\mathrm{POH} / \beta-\mathrm{CD}(50 \mathrm{mg} / \mathrm{kg})$ (Figure 9).

In the present study, immunostaining for the Ki67 antigen was evidenced predominantly in the nuclei, corroborating the classic pattern of immunoexpression described in previous studies with sarcoma 180 [38]. However, eventually and surprisingly, focal areas of cytoplasmic/membranous immunostaining of this antigen were also found. This atypical marking pattern for the Ki67 antigen has been described previously [57] but the mechanisms behind this phenomenon and its real clinical significance remain unclear. It has been suggested that this pattern of immunostaining would occur for three possible reasons: (i) an alleged cross-reaction with other cytoplasmic antigens similar to the histone ki67 nuclear protein; (ii) technical artefacts and (iii) possible relocation of the Ki67 protein from the nucleus to the cytoplasm during the cell cycle [58].

In our work, nuclear immunoexpression of the Ki67 antigen was reduced in the groups treated with $5-\mathrm{FU}$ and $\mathrm{POH} / \beta-\mathrm{CD}(50 \mathrm{mg} / \mathrm{Kg})$ compared to the group treated with the vehicle. These data suggest a significant reduction of cycling cells (in proliferation) and seem to agree with the results obtained in both macroscopic analyses of the inhibition of neoplastic growth and in the study of the histological characteristics of experimental tumors. On the other hand, the mechanisms that determine these results have yet to be investigated, as they could result both from the possible blockage of the cell cycle and from the increase in death due to apoptosis of cycling cells. It is important to note that, since 
the areas of coagulative necrosis were much less extensive in these two groups (5FU and $\mathrm{POH} / \beta-\mathrm{CD}(50 \mathrm{mg} / \mathrm{Kg})$, it is possible that speculation that the smallest tumor growth by inducing a higher rate of necrosis is unlikely. Thus, further studies are needed in order to elucidate this issue.

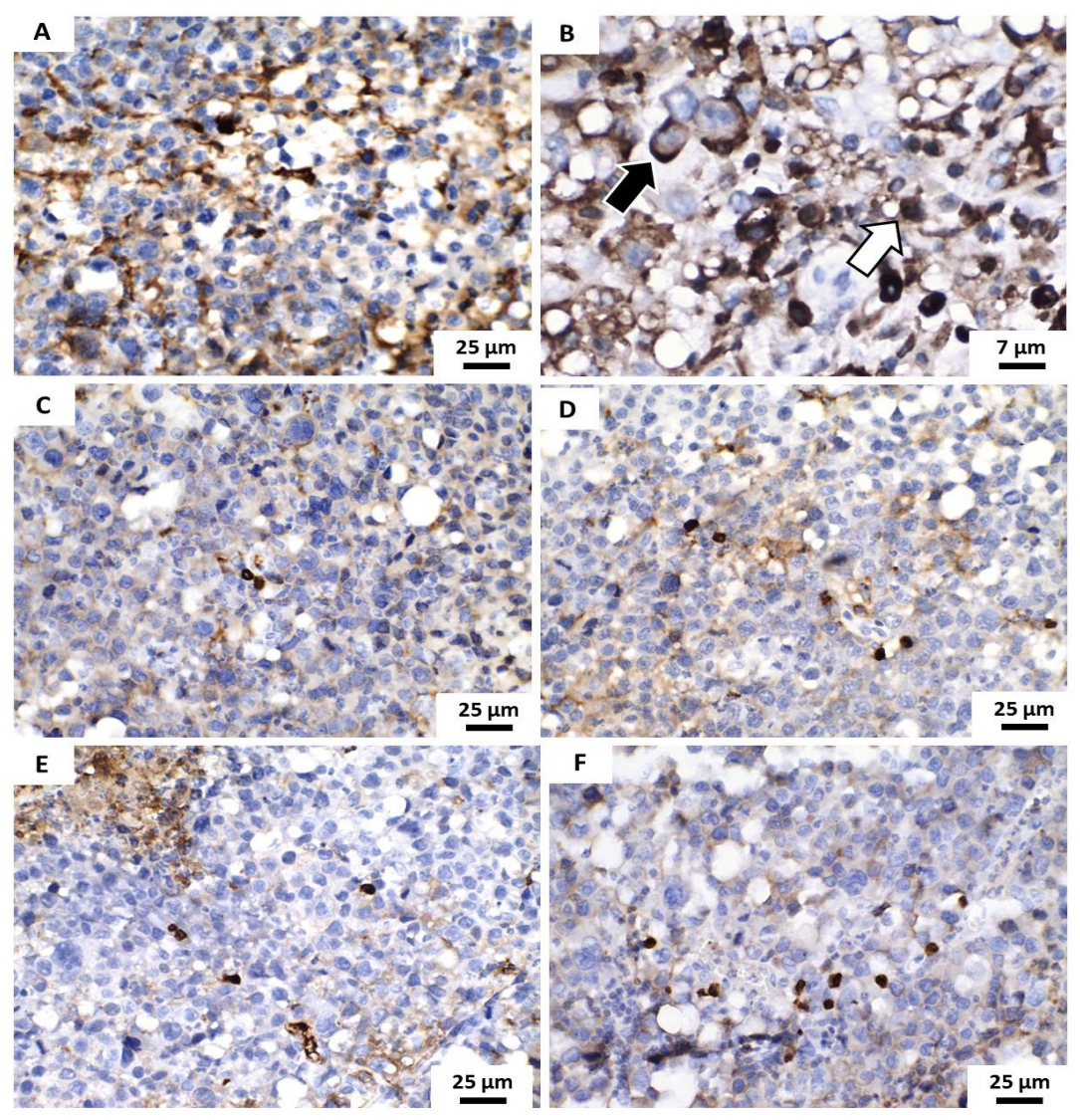

Figure 9. Photomicrographs of histological sections demonstrate the immunohistochemical expression of the Ki67 antigen (brownish color) in the analyzed tumors. (A,B) Vehicle Group shows tumor cells showed predominantly nuclear positivity (light arrow) and eventually, cytoplasmic immunoexpression of this antigen (dark arrow). (C-F) represent the groups treated with $5-\mathrm{FU}(25 \mathrm{mg} / \mathrm{Kg} /$ day) and 50, 100 and $200 \mathrm{mg} / \mathrm{Kg} /$ day of the formulation contain $\mathrm{POH} / \beta-\mathrm{CD}$ inclusion complex.

\section{Conclusions}

In this work, perillyl alcohol/ $\beta$-cyclodextrin (1:1) inclusion complexes have been successfully obtained. Three distinct complexation approaches have been adopted, while molecular docking confirmed the hydrogen-bond interaction between $\beta$-cyclodextrin. The best interaction was seen for the complexes obtained by co-evaporation. The formation of this inclusion complex was also demonstrated by SEM, as a homogenous $\beta$-CD crystal was obtained after the $\mathrm{POH}$ inclusion, in contrast to the pure $\beta-\mathrm{CD}$. The inclusion of $\mathrm{POH}$ in $\beta$-cyclodextrin resulted in $100 \%$ of cell viability after $24 \mathrm{~h}$ against human fibroblast line L929. From the histopathological analysis, the in vivo studies in S180-induced mice treated with $\mathrm{POH} / \beta-\mathrm{CD}$ at a dose of $50 \mathrm{mg} / \mathrm{kg}$ demonstrated the inhibition of tumor growth about $60 \%$. In situ immunostaining of the Ki67 antigen was used to analyze tumor proliferation also showing a significant reduction of cycling cells. Our results anticipate the potential advantages of using monoterpene of essential oil—perillyl alcohol—as an anti-tumor drug, emphasizing the added value of CD-docking as an approach to improve the drug's performance in vitro and in vivo, while reducing the risk of volatility.

Supplementary Materials: The following are available online at https: / www.mdpi.com/1999-4 923/13/2/245/s1, Figure S1: DSC thermogram (A) Perillyl alcohol, (B) $\beta$-cyclodextrin, (C) Co- 
evaporation, (D) Malaxation and (E) Physi-cal mixture, Figure S2: TG/DTGG curves of (A) Perillyl alcohol, (B) $\beta$-cyclodextrin, (C) Co-evaporation, (D) Malaxation and (E) Physical mixture.

Author Contributions: All authors have made a substantial contribution to the work. A.A.R., R.S.S., L.N.A., R.G.A., M.M.P., C.B., M.C. and C.B. contributed for the conceptualization, methodology, validation, formal analysis and investigation; R.S.S., P.S. and R.L.C.d.A.J. contributed for the writing-original draft preparation; M.C., R.P., C.F.d.S., R.L.C.d.A.J., E.B.S. and P.S. contributed for the supervision, writing the second version, editing the revision, project administration, resources and funding acquisition. All authors have read and agreed to the published version of the manuscript.

Funding: This work was supported by the Banco do Nordeste (grant FUNDECI/2016.0015), Conselho Nacional de Desenvolvimento Científico e Tecnológico (CNPq), Fundação de Apoio à Pesquisa e à Inovação Tecnológica do Estado de Sergipe (Fapitec) and Coordenação de Aperfeiçoamento de Pessoal de Nível Superior (CAPES). Eliana B. Souto would like to acknowledge the Portuguese Science and Technology Foundation (FCT/MCT) and from European Funds (PRODER/COMPETE) for the project UIDB/04469/2020 (strategic fund), co-financed by FEDER, under the Partnership Agreement PT2020.

Institutional Review Board Statement: Not applicable.

Informed Consent Statement: Not applicable.

Data Availability Statement: The data presented in this study are available on request from the corresponding authors.

Conflicts of Interest: The authors declare no conflict of interest.

\section{References}

1. Cardoso-Teixeira, A.C.; Ferreira-da-Silva, F.B.; Peixoto-Neves, D.; Oliveira-Abreu, K.; Pereira-Gonçalves, Á.; Coelho-de-Souza, A.N.; Leal-Cardoso, J.N. Hydroxyl Group and Vasorelaxant Effects of Perillyl Alcohol, Carveol, Limonene on Aorta Smooth Muscle of Rats. Molecules 2018, 23, 1430. [CrossRef] [PubMed]

2. Cavendish, M.; Nalone, L.; Barbosa, T.; Barbosa, R.; Costa, S.; Nunes, R.; da Silva, C.F.; Chaud, M.V.; Souto, E.B.; Hollanda, L. Study of pre-formulation and development of solid lipid nanoparticles containing perillyl alcohol. J. Therm. Anal. Calorim. 2019, 1-8. [CrossRef]

3. Marín-Ramos, N.I.; Jhaveri, N.; Thein, T.Z.; Fayngor, R.A.; Chen, T.C.; Hofman, F.M. NEO212, a conjugate of temozolomide and perillyl alcohol, blocks the endothelial-to-mesenchymal transition in tumor-associated brain endothelial cells in glioblastoma. Cancer Lett. 2019, 442, 170-180. [CrossRef] [PubMed]

4. Da Fonseca, C.O.; Simao, M.; Lins, I.R.; Caetano, R.O.; Futuro, D.; Quirico-Santos, T. Efficacy of monoterpene perillyl alcohol upon survival rate of patients with recurrent glioblastoma. J. Cancer Res. Clin. Oncol. 2011, 137, 287-293. [CrossRef] [PubMed]

5. Da Fonseca, C.O.; Teixeira, R.M.; Ramina, R.; Kovaleski, G.; Silva, J.T.; Nagel, J.; Quirico-Santos, T. Case of advanced recurrent glioblastoma successfully treated with monoterpene perillyl alcohol by intranasal administration. J. Cancer Ther. 2011, 2, 16-21. [CrossRef]

6. Faria, G.; Silva, E.; Da Fonseca, C.; Quirico-Santos, T. Circulating cell-free DNA as a prognostic and molecular marker for patients with brain tumors under perillyl alcohol-based therapy. Int. J. Mol. Sci. 2018, 19, 1610. [CrossRef] [PubMed]

7. Song, M.M.; Makena, M.R.; Hindle, A.; Koneru, B.; Nguyen, T.H.; Verlekar, D.U.; Cho, H.; Maurer, B.J.; Kang, M.H.; Reynolds, C.P. Cytotoxicity and molecular activity of fenretinide and metabolites in T-cell lymphoid malignancy, neuroblastoma, and ovarian cancer cell lines in physiological hypoxia. Anti Cancer Drugs 2019, 30, 117-127. [CrossRef]

8. Souto, E.B.; Souto, S.B.; Zielinska, A.; Durazzo, A.; Lucarini, M.; Santini, A.; Horbańczuk, O.K.; Atanasov, A.G.; Marques, C.; Andrade, L.N.; et al. Perillaldehyde 1,2-epoxide loaded SLN-tailored mAb: Production, physicochemical characterization and in vitro cytotoxicity profile in MCF-7 cell lines. Pharmaceutics 2020, 12, 161. [CrossRef] [PubMed]

9. Souto, E.B.; Zielinska, A.; Souto, S.B.; Durazzo, A.; Lucarini, M.; Santini, A.; Silva, A.M.; Atanasov, A.G.; Marques, C.; Andrade, L.N.; et al. (+)-Limonene 1,2-epoxide-loaded SLN: Evaluation of drug release, antioxidant activity and cytotoxicity in HaCaT cell line. Int. J. Mol. Sci. 2020, 21, 1449. [CrossRef] [PubMed]

10. Chen, M.; Peérez, R.L.; Du, P.; Bhattarai, N.; McDonough, K.C.; Ravula, S.; Kumar, R.; Mathis, J.M.; Warner, I.M. Tumor-Targeting NIRF NanoGUMBOS with Cyclodextrin-Enhanced Chemo/Photothermal Antitumor Activities. ACS Appl. Mater. Interfaces 2019, 11, 27548-27557. [CrossRef] [PubMed]

11. Crupi, V.; Majolino, D.; Venuti, V.; Guella, G.; Mancini, I.; Rossi, B.; Verrocchio, P.; Viliani, G.; Stancanelli, R. Temperature effect on the vibrational dynamics of cyclodextrin inclusion complexes: Investigation by FTIR-ATR spectroscopy and numerical simulation. J. Phys. Chem. A 2010, 114, 6811-6817. [CrossRef] [PubMed]

12. Crupi, V.; Guella, G.; Majolino, D.; Mancini, I.; Rossi, B.; Stancanelli, R.; Venuti, V.; Verrocchio, P.; Viliani, G. T-dependence of the vibrational dynamics of IBP/diME- $\beta$-CD in solid state: A FT-IR spectral and quantum chemical study. J. Mol. Struct. 2010, 972, 75-80. [CrossRef] 
13. Venturini, C.d.G.; Nicolini, J.; Machado, C.; Machado, V.G. Properties and recent applications of cyclodextrins. Quim. Nova 2008, 31, 360-368. [CrossRef]

14. Youn, Y.S.; Bae, Y.H. Perspectives on the past, present, and future of cancer nanomedicine. Adv. Drug Deliv. Rev. 2018, 130, 3-11. [CrossRef] [PubMed]

15. Falke, J.; Parkkinen, J.; Vaahtera, L.; Hulsbergen-van de Kaa, C.; Oosterwijk, E.; Witjes, J. Curcumin as treatment for bladder cancer: A preclinical study of cyclodextrin-curcumin complex and BCG as intravesical treatment in an orthotopic bladder cancer rat model. BioMed Res. Int. 2018, 2018, 9634902. [CrossRef]

16. Elamin, K.M.; Motoyama, K.; Higashi, T.; Yamashita, Y.; Tokuda, A.; Arima, H. Dual targeting system by supramolecular complex of folate-conjugated methyl- $\beta$-cyclodextrin with adamantane-grafted hyaluronic acid for the treatment of colorectal cancer. Int. J. Biol. Macromol. 2018, 113, 386-394. [CrossRef] [PubMed]

17. Hu, S.C.-S.; Lai, Y.-C.; Lin, C.-L.; Tzeng, W.-S.; Yen, F.-L. Inclusion complex of saikosaponin-d with hydroxypropyl- $\beta$-cyclodextrin: Improved physicochemical properties and anti-skin cancer activity. Phytomedicine 2019, 57, 174-182. [CrossRef]

18. Rescifina, A.; Surdo, E.; Cardile, V.; Avola, R.; Graziano, A.C.E.; Stancanelli, R.; Tommasini, S.; Pistarà, V.; Ventura, C.A. Gemcitabine anticancer activity enhancement by water soluble celecoxib/sulfobutyl ether- $\beta$-cyclodextrin inclusion complex. Carbohydr. Polym. 2019, 206, 792-800. [CrossRef]

19. Vaidya, B.; Shukla, S.K.; Kolluru, S.; Huen, M.; Mulla, N.; Mehra, N.; Kanabar, D.; Palakurthi, S.; Ayehunie, S.; Muth, A. Nintedanib-cyclodextrin complex to improve bio-activity and intestinal permeability. Carbohydr. Polym. 2019, 204, 68-77. [CrossRef]

20. Yang, H.; Pan, Z.; Jin, W.; Zhao, L.; Xie, P.; Chi, S.; Lei, Z.; Zhu, H.; Zhao, Y. Preparation, characterization and cytotoxic evaluation of inclusion complexes between celastrol with polyamine-modified $\beta$-cyclodextrins. J. Incl. Phenom. Macrocycl. Chem. 2019, 95, 147-157. [CrossRef]

21. Trindade, G.G.; Thrivikraman, G.; Menezes, P.P.; França, C.M.; Lima, B.S.; Carvalho, Y.M.; Souza, E.P.; Duarte, M.C.; Shanmugam, S.; Quintans-Júnior, L.J. Carvacrol/ $\beta$-cyclodextrin inclusion complex inhibits cell proliferation and migration of prostate cancer cells. Food Chem. Toxicol. 2019, 125, 198-209. [CrossRef]

22. Fan, W.; Xu, Y.; Li, Z.; Li, Q. Folic acid-modified $\beta$-cyclodextrin nanoparticles as drug delivery to load DOX for liver cancer therapeutics. Soft Mater. 2019, 17, 437-447. [CrossRef]

23. Aditya, N.P.; Vathsala, P.G.; Vieira, V.; Murthy, R.S.; Souto, E.B. Advances in nanomedicines for malaria treatment. Adv. Colloid Interface Sci. 2013, 201, 1-17. [CrossRef]

24. Fangueiro, J.F.; Souto, E.B.; Silva, A.M. 9-Encapsulation of nutraceuticals in novel delivery systems. In Nutraceuticals; Grumezescu, A.M., Ed.; Academic Press: Cambridge, MA, USA, 2016; pp. 305-342. [CrossRef]

25. Fumić, B.; Jablan, J.; Cinčić, D.; Zovko Končić, M.; Jug, M. Cyclodextrin encapsulation of daidzein and genistein by grinding: Implication on the glycosaminoglycan accumulation in mucopolysaccharidosis type II and III fibroblasts. J. Microencapsul. 2018, 35, 1-12. [CrossRef]

26. Fontinele, L.L.; Heimfarth, L.; Pereira, E.W.M.; Rezende, M.M.; Lima, N.T.; de Carvalho, Y.M.B.G.; de Moura Pires, E.A.; Guimarães, A.G.; Carvalho, M.T.B.; Barreto, R.d.S.S. Anti-hyperalgesic effect of (-)- $\alpha$-bisabolol and (-)- $\alpha$-bisabolol/ $\beta$-Cyclodextrin complex in a chronic inflammatory pain model is associated with reduced reactive gliosis and cytokine modulation. Neurochem. Int. 2019, 131, 104530. [CrossRef] [PubMed]

27. Bíró, T.; Horvát, G.; Budai-Szúcs, M.; Csányi, E.; Urbán, E.; Facskó, A.; Szabó-Révész, P.; Csóka, I.; Aigner, Z. Development of prednisolone-containing eye drop formulations by cyclodextrin complexation and antimicrobial, mucoadhesive biopolymer. Drug Des. Dev. Ther. 2018, 12, 2529. [CrossRef]

28. Rodríguez-López, M.I.; Mercader-Ros, M.T.; Pellicer, J.A.; Gómez-López, V.M.; Martínez-Romero, D.; Núñez-Delicado, E.; Gabaldón, J.A. Evaluation of monoterpene-cyclodextrin complexes as bacterial growth effective hurdles. Food Control 2020, 108, 106814. [CrossRef]

29. Li, N.; Wang, N.; Wu, T.; Qiu, C.; Wang, X.; Jiang, S.; Zhang, Z.; Liu, T.; Wei, C.; Wang, T. Preparation of curcumin-hydroxypropyl$\beta$-cyclodextrin inclusion complex by cosolvency-lyophilization procedure to enhance oral bioavailability of the drug. Drug Dev. Ind. Pharm. 2018, 44, 1966-1974. [CrossRef] [PubMed]

30. Carneiro, S.B.; Costa Duarte, F.I.; Heimfarth, L.; de Souza Siqueira Quintans, J.; Quintans-Júnior, L.J.; da Veiga Júnior, V.F.; Neves de Lima, Á.A. Cyclodextrin-Drug Inclusion Complexes: In Vivo and In Vitro Approaches. Int. J. Mol. Sci. 2019, 20, 642. [CrossRef]

31. Trott, O.; Olson, A.J. AutoDock Vina: Improving the speed and accuracy of docking with a new scoring function, efficient optimization, and multithreading. J. Comput. Chem. 2010, 31, 455-461. [CrossRef]

32. Morris, G.M.; Huey, R.; Lindstrom, W.; Sanner, M.F.; Belew, R.K.; Goodsell, D.S.; Olson, A.J. AutoDock4 and AutoDockTools4: Automated docking with selective receptor flexibility. J. Comput. Chem. 2009, 30, 2785-2791. [CrossRef]

33. Rezende, A.A. In Vivo Antitumoral Activity of Perillylalcohol Incorporated in $\beta$-Cyclodextrin Complexes. Master's Thesis, University of Tiradentes, Aracaju, Sergipe, Brazil, 2020.

34. Al-Nasiri, G.; Cran, M.J.; Smallridge, A.J.; Bigger, S.W. Optimisation of $\beta$-cyclodextrin inclusion complexes with natural antimicrobial agents: Thymol, carvacrol and linalool. J. Microencapsul. 2018, 35, 26-35. [CrossRef]

35. Oliveira, M.G.; Brito, R.G.; Santos, P.L.; Araújo-Filho, H.G.; Quintans, J.S.; Menezes, P.P.; Serafini, M.R.; Carvalho, Y.M.; Silva, J.C.; Almeida, J.R.; et al. $\alpha$-Terpineol, a monoterpene alcohol, complexed with $\beta$-cyclodextrin exerts antihyperalgesic effect in animal model for fibromyalgia aided with docking study. Chem. Biol. Interact. 2016, 254, 54-62. [CrossRef] 
36. Miller, F.; Hinze, U.; Chichkov, B.; Leibold, W.; Lenarz, T.; Paasche, G. Validation of eGFP fluorescence intensity for testing in vitro cytotoxicity according to ISO 10993-5. J. Biomed. Mater. Res. Part B Appl. Biomater. 2017, 105, 715-722. [CrossRef]

37. Andrade, L.N.; Amaral, R.G.; Dória, G.A.; Fonseca, C.S.; da Silva, T.K.; Albuquerque Júnior, R.L.; Thomazzi, S.M.; do Nascimento, L.G.; Carvalho, A.A.; de Sousa, D.P. In Vivo Anti-Tumor Activity and Toxicological Evaluations of Perillaldehyde 8,9-Epoxide, a Derivative of Perillyl Alcohol. Int. J. Mol. Sci. 2016, 17, 32. [CrossRef]

38. Bezerra, D.; Castro, F.; Alves, A.; Pessoa, C.; Moraes, M.; Silveira, E.; Lima, M.; Elmiro, F.; Costa-Lotufo, L. In vivo growthinhibition of Sarcoma 180 by piplartine and piperine, two alkaloid amides from Piper. Braz. J. Med. Biol. Res. 2006, 39, 801-807. [CrossRef] [PubMed]

39. Andrade, L.N.; Severino, P.; Amaral, R.G.; Anne, G.; Dória, A.; da Silva, A.; Alves, M.; Albuquerque, R.L.C.; de Sousa, D.P. Evaluation of cytotoxic and antitumor activity of perillaldehyde 1, 2-epoxide. J. Med. Plants Res. 2018, 12, 590-600.

40. Sousa, S.F.; Fernandes, P.A.; Ramos, M.J. Protein-ligand docking: Current status and future challenges. Proteins 2006, 65, 15-26. [CrossRef]

41. Dallakyan, S.; Olson, A.J. Small-molecule library screening by docking with PyRx. In Chemical Biology; Springer: Cham, Switzerland, 2015; pp. 243-250.

42. Siqueira-Lima, P.S.; Brito, R.G.; Araújo-Filho, H.G.; Santos, P.L.; Lucchesi, A.; Araújo, A.A.; Menezes, P.P.; Scotti, L.; Scotti, M.T.; Menezes, I.R. Anti-hyperalgesic effect of Lippia grata leaf essential oil complexed with $\beta$-cyclodextrin in a chronic musculoskeletal pain animal model: Complemented with a molecular docking and antioxidant screening. Biomed. Pharmacother. 2017, 91, 739-747. [CrossRef]

43. Menezes, P.P.; Serafini, M.R.; Quintans-Júnior, L.J.; Silva, G.F.; Oliveira, J.F.; Carvalho, F.M.S.; Souza, J.C.C.; Matos, J.R.; Alves, P.B.; Matos, I.L.; et al. Inclusion complex of (-)-linalool and $\beta$-cyclodextrin. J. Therm. Anal. Calorim. 2014, 115, 2429-2437. [CrossRef]

44. Mura, P. Analytical techniques for characterization of cyclodextrin complexes in the solid state: A review. J. Pharm. Biomed. Anal. 2015, 113, 226-238. [CrossRef]

45. Aigner, Z.; Berkesi, O.; Farkas, G.; Szabó-Révész, P. DSC, X-ray and FTIR studies of a gemfibrozil/dimethyl- $\beta$-cyclodextrin inclusion complex produced by co-grinding. J. Pharm. Biomed. Anal. 2012, 57, 62-67. [CrossRef]

46. Marques, C.S.F.; Barreto, N.S.; Oliveira, S.S.C.d.; Santos, A.L.S.; Branquinha, M.H.; Sousa, D.P.d.; Castro, M.; Andrade, L.N.; Pereira, M.M.; Silva, C.F.d.; et al. $\beta$-Cyclodextrin/Isopentyl Caffeate Inclusion Complex: Synthesis, Characterization and Antileishmanial Activity. Molecules 2020, 25, 4181. [CrossRef] [PubMed]

47. Kfoury, M.; Auezova, L.; Fourmentin, S.; Greige-Gerges, H. Investigation of monoterpenes complexation with hydroxypropyl- $\beta$ cyclodextrin. J. Incl. Phenom. Macrocycl. Chem. 2014, 80, 51-60. [CrossRef]

48. Guimarães, A.G.; Oliveira, M.A.; Alves Rdos, S.; Menezes Pdos, P.; Serafini, M.R.; Araújo, A.A.; Bezerra, D.P.; Quintans Júnior, L.J. Encapsulation of carvacrol, a monoterpene present in the essential oil of oregano, with $\beta$-cyclodextrin, improves the pharmacological response on cancer pain experimental protocols. Chem. Biol. Interact. 2015, 227, 69-76. [CrossRef]

49. Santos, P.L.; Brito, R.G.; Oliveira, M.A.; Quintans, J.S.; Guimarães, A.G.; Santos, M.R.; Menezes, P.P.; Serafini, M.R.; Menezes, I.R.; Coutinho, H.D.; et al. Docking, characterization and investigation of $\beta$-cyclodextrin complexed with citronellal, a monoterpene present in the essential oil of Cymbopogon species, as an anti-hyperalgesic agent in chronic muscle pain model. Phytomedicine 2016, 23, 948-957. [CrossRef] [PubMed]

50. El-Sayed, M.; Simon, M.A.; El-Wasify, M.; Nambiar, V. Medical students' perception of teaching evaluation and feedback: A study at Oman Medical College. Middle East Curr. Psychiatry 2018, 25, 131-134. [CrossRef]

51. Efferth, T.; Saeed, M.E.; Kadioglu, O.; Seo, E.-J.; Shirooie, S.; Mbaveng, A.T.; Nabavi, S.M.; Kuete, V. Collateral sensitivity of natural products in drug-resistant cancer cells. Biotechnol. Adv. 2020, 38, 107342. [CrossRef]

52. Kroschinsky, F.; Stölzel, F.; von Bonin, S.; Beutel, G.; Kochanek, M.; Kiehl, M.; Schellongowski, P. New drugs, new toxicities: Severe side effects of modern targeted and immunotherapy of cancer and their management. Crit. Care 2017, 21, 89. [CrossRef]

53. Pavithra, P.; Mehta, A.; Verma, R.S. Aromadendrene oxide 2, induces apoptosis in skin epidermoid cancer cells through ROS mediated mitochondrial pathway. Life Sci. 2018, 197, 19-29. [CrossRef]

54. Levrier, C.; Rockstroh, A.; Gabrielli, B.; Kavallaris, M.; Lehman, M.; Davis, R.A.; Sadowski, M.C.; Nelson, C.C. Discovery of thalicthuberine as a novel antimitotic agent from nature that disrupts microtubule dynamics and induces apoptosis in prostate cancer cells. Cell Cycle 2018, 17, 652-668. [CrossRef] [PubMed]

55. Debnath, S.; Mukherjee, A.; Karan, S.; Debnath, M.; Chatterjee, T.K. Induction of apoptosis, anti-proliferation, tumor-angiogenic suppression and down-regulation of Dalton's Ascitic Lymphoma (DAL) induced tumorigenesis by poly-l-lysine: A mechanistic study. Biomed. Pharmacother. 2018, 102, 1064-1076. [CrossRef]

56. Graefe, C.; Eichhorn, L.; Wurst, P.; Kleiner, J.; Heine, A.; Panetas, I.; Abdulla, Z.; Hoeft, A.; Frede, S.; Kurts, C. Optimized Ki-67 staining in murine cells: A tool to determine cell proliferation. Mol. Biol. Rep. 2019, 46, 4631-4643. [CrossRef]

57. Faratian, D.; Munro, A.; Twelves, C.; Bartlett, J.M. Membranous and cytoplasmic staining of Ki67 is associated with HER2 and ER status in invasive breast carcinoma. Histopathology 2009, 54, 254-257. [CrossRef] [PubMed]

58. Leonardo, E.; Volante, M.; Barbareschi, M.; Cavazza, A.; Dei Tos, A.P.; Bussolati, G.; Papotti, M. Cell membrane reactivity of MIB-1 antibody to Ki67 in human tumors: Fact or artifact? Appl. Immunohistochem. Mol. Morphol. 2007, 15, 220-223. [CrossRef] [PubMed] 